\title{
Rare Middle and Upper Devonian dalmanelloid (Orthida) of the Cantabrian Mountains, N Spain
}

\author{
Jenaro L. GARCÍA-ALCALDE
}

Departamento de Geología, Universidad de Oviedo, c/ Jesús Arias de Velasco s/n, 33005 Oviedo, Spain; jalcalde@geol.uniovi.es

García-Alcalde, J.L. 2018. Rare Middle and Upper Devonian dalmanelloid (Orthida) of the Cantabrian Mountains, N Spain. [Formas raras de dalmaneloideos (Orthida) del Devónico Medio y Superior de la Cordillera Cantábrica, N España]. Spanish Journal of Palaeontology, 33 (1), 57-82.

\begin{abstract}
Rare Cantabrian Dalmanellidae (Costisorthis lisae nov. sp.), Dicoelosiidae (Teichertina cf. peregrina, T. cf. fitzroyensis), and Mystrophoridae (Mystrophora sp., Biernatium sucoi nov. sp., and Biernatium sp. 2) are described and figured for the first time in Spain. Most of them are scarce forms that occur only in certain localities. All the species but one came from the lower part of the Portilla (province of León) and Candás (province of Asturias) formations, Faunal Interval 21, Polygnathus rhenanus/P. varcus conodont zone, middle Givetian. The exception is Biernatium sp. 2 that occurs in Asturias in FI 25, Piñeres Fm., Palmatolepis transitans zone, lower Frasnian. Costisorthis ranges from Pragian to Eifelian rocks in central Europe. C. lisae nov. sp., from the Givetian of Asturias differs from other Costisorthis species in the weaker development of the distinctive ventral and dorsal plications. Teichertina is a bizarre, bisulcate spiriferoid-like taxon previously known from the Pragian to Frasnian of central Europe, NE Russia, west-central Alaska, Nevada, China and Western Australia. T. cf. fitzroyensis, from the Givetian of Asturias and Leon, is smaller than T. fitzroyensis. Its ventral sulcus and costellate ornamentation are weaker than the nominal species. $T$. cf. peregrina from the Givetian of Leon, is very close to the nominal species. Biernatium includes Pragian to Frasnian age species from central Europe (Poland, Moravia), and Western Australia. Kayserella costatula from the Pragian-Zlichovian
\end{abstract}

\section{RESUMEN}

Se describen y figuran por primera vez en España braquiópodos órtidos inusuales de las familias Dalmanellidae (Costisorthis lisae n. sp), Dicoelosiidae (Teichertina cf. peregrina y Teichertina cf. fitzroyensis) y Mystrophoridae (Mystrophora sp., Biernatium sucoi nov. sp. y Biernatium sp. 2). La mayoría de ellos son escasos y aparecen en localidades puntuales. Todas las especies menos una proceden de la parte baja de las formaciones Portilla (en León) y Candás (en Asturias), Intervalo Faunístico 21, Biozona de Polygnathus rhenanus/P. varcus, Givetiense medio. La excepción la constituye Biernatium sp. 2, de la Fm. Piñeres, en Asturias, IF 25, Biozona de Palmatolepis transitans, Frasniense inferior. Costisorthis se conocía anteriormente del Praguiense al Eifeliense de Europa Central. C. lisae n. sp, del Givetiense de Asturias, difiere de otras especies del género en el menor desarrollo de los característicos repliegues medios de la concha. Teichertina es un taxón extraño de aspecto espiriferoide, conocido del Praguiense al Frasniense de Europa Central, NE de Rusia, Alaska centro-occidental, Nevada, China y Australia Occidental. T. cf. fitzroyensis, del Givetiense de Asturias y León es algo más pequeña, y con surco peduncular y ornamentación costulada más débiles que la especie nominal. $T$. cf. peregrina del Givetiense de León, es muy parecida a la especie nominal. Biernatium agrupaba especies del Praguiense al Frasniense, de Europa 
of the Yukon (northwestern Canada) is also placed in the genus due to its long cruralium. The Cantabrian Biernatium species have the characteristic high dorsal septum and large cruralium of the genus, but $B$. sp. 2 is smaller and with a more branched radial ornament pattern than $B$. sucoi nov. sp. The good preservation of $B$. sucoi nov. sp. collections allows for the study of its ontogeny and phylogenetic relationships. $B$. sp. 2 very probably evolved from $B$. sucoi nov. sp. by extension of the rib branching along the entire shell or nearly so. Mystrophora is close to Biernatium but it is provided with fulcral plates that are lacking in Biernatium, and by a shorter and more elaborate cruralium. The taxon was previously known in beds of Pragian to Eifelian age in northwestern Canada, Eastern Australia, Burma, Europe (Germany, Belgium, and France), and, questionably in the Mongol-Okhotsk area of the Siberian block. $M$. sp. from the middle Givetian of León is characterized by a larger sized shell than is usual for the genus.

Keywords: Dalmanelloids, systematics, ontogeny, phylogeny, palaeobiogeography.
Central (Polonia y Moravia) y Australia Occidental. Los taxones cantábricos poseen el distintivo septo dorsal, muy alto, y extenso cruralio del género, pero $B$. sp. 2 es algo más pequeña y con ornamentación radial más fascicostulada que la de $B$. sucoi nov. sp. La buena conservación del material tipo de B. sucoi nov. sp. permitió estudiar la ontogenia de la especie y sus relaciones filogenéticas. Mystrophora se parece a Biernatium, pero posee placas fulcrales y cruralio más corto y elaborado. El género se conocía desde el Praguiense al Eifeliense del Noroeste de Canadá, Australia Oriental, Burma, Europa (Alemania, Bélgica y Francia) y, cuestionablemente, en el área Mongol-Okhotsk, del bloque siberiano. $M$. sp., de León, se caracteriza por su tamaño más grande de lo habitual en el género.

Palabras clave: Dalmanélidos, Sistemática, Ontogenia, Filogenia, Paleobiogeografía.

\section{INTRODUCTION}

Among the abundant and diverse Cantabrian Mts (N Spain) Devonian dalmanelloids (Orthida, articulate brachiopods) this paper deals with those that by different reasons have not even been noticed to family scale by Spanish and foreign brachiopod workers. A part of them are specialized forms from very restricted areas and stratigraphical levels; i.e. the isorthine Costisorthis lisae nov. sp. has been identified after a small collection sampled in the lower part of the Candás Formation in a single Asturian locality (Figs 1,4). A different situation is that of several minute septate Dicoelosiidae Cloud, 1948 and Mystrophoridae Schuchert \& Cooper, 1931. These forms went perhaps unnoticed due either to its small size and to its rarity. They belong to genera poorly known everywhere and at least two of them to new species. Biernatium sucoi nov. sp. is the sole taxon represented by abundant and well-preserved material. In turn, only two specimens of Teichertina cf. fitzroyensis are available, one of both, Teichertina cf. peregrina and Mystrophora sp., and eleven of Biernatium sp. 2 .

A great part of the studied collections comes from the lower tiers of the Portilla and the Candás formations, provinces of León and Asturias (N Spain) (Fig. 1), respectively. They belong in the upper part of the Faunal Interval 21 (García-Alcalde, 1996), Polygnathus rhenanus/ varcus conodont zone (García-López \& Sanz-López, 2002a, 2000b), mid Givetian. The sampled Asturo-Leonian near-shore successions correspond to the last Cantabrian Devonian main reef cycle (Third reef episode, in MéndezBedia et al., 1994; episodio $V$, in Fernández-Martínez et al., 2008). The critical levels abound usually in alveolitid tabulate corals with aboral sides colonized by fixosessile forms of Davidsonia verneuili Bouchard-Chantereaux, 1849. These levels are close in time to the offshore facies where the Pumilio Event (Lottmann, 1990) has been recorded everywhere. This fact could perhaps explain the originality of the studied faunas. Biernatium sp. 2 is a younger early Frasnian form that occurs in the upper part of the Piñeres Formation sensu García-Alcalde (1985). It is associated there with a distinctive shelly fauna, from the upper part of the Faunal Interval 25, Palmatolepis transitans zone (García-López \& Sanz-López, 2002a), with Cariniferella dumontiana, Apousiella cf. belliloci, Warrenella cf. euryglossa, and Phlogoiderhynchus sp. $A$, among others. Biernatium sp. 2 and B. emanuelensis (Veevers, 1959), from NW Australia, are the sole known Upper Devonian Biernatium species. As discussed below, $B$. sp. 2 could have evolved from $B$. sucoi nov. sp. by rise of an ornamental complexity with bundles of ribs extending to the greater part of shell.

The occurrence in the Cantabrian Mountains of the described forms contributes to the improvement of the mid Givetian to early Frasnian palaeobiogeographic perspective (Fig. 2). Apparently, the studied taxa could have reached the Cantabrian region during a Rheic Ocean narrowing period that made possible important southwards and westwards migrations from central-Europe terranes.

The new taxa, Costisorthis lisae nov. sp. and Biernatium sucoi nov. sp. have been dedicated, respectively, to Prof. María Luisa Martínez-Chacón, long time editor of the Sociedad Española de Paleontología bulletin, and to her husband Prof. Luis Carlos Sánchez de Posada, former president of the Sociedad Española de Paleontología, 


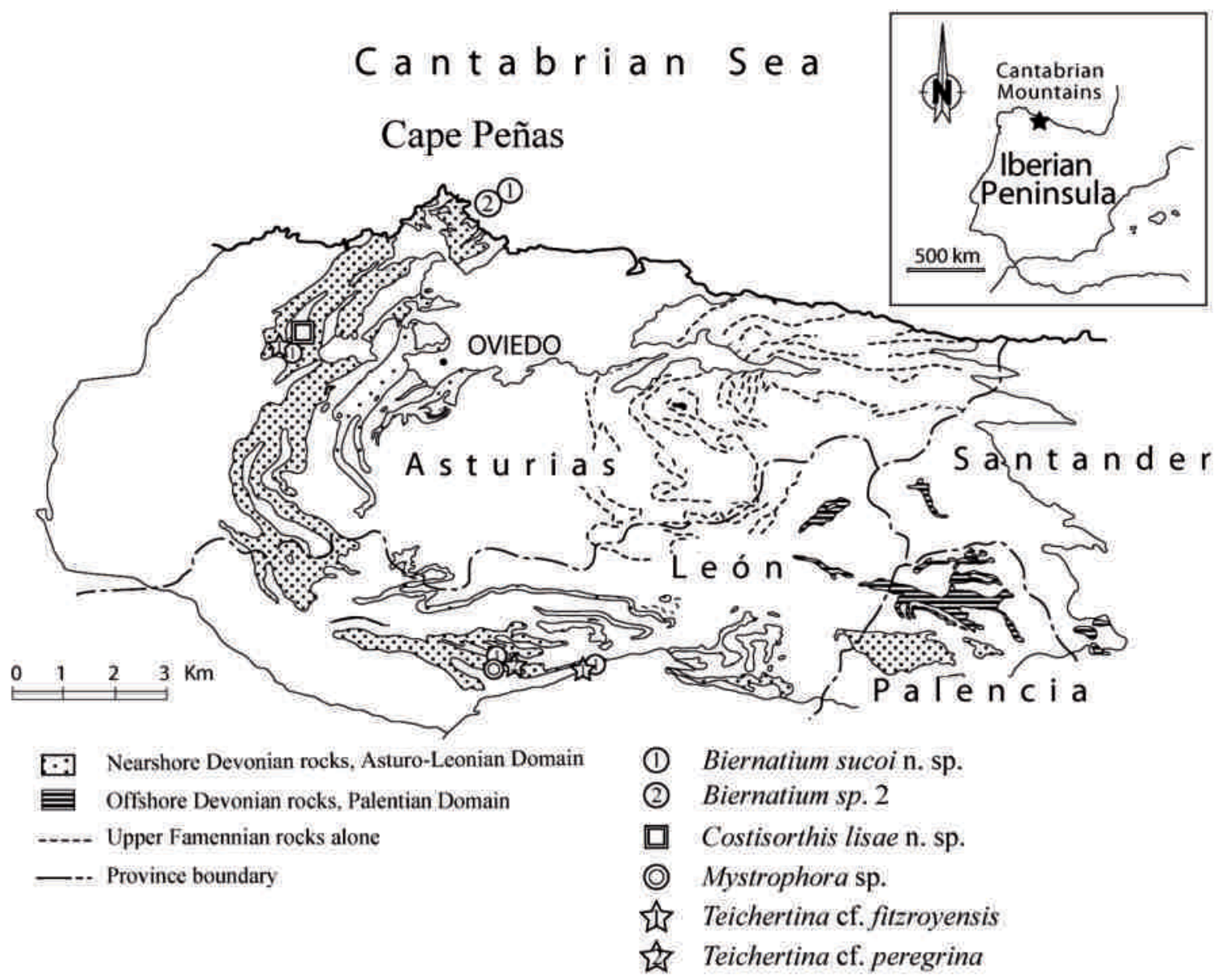

Figure 1. General setting of the studied species in the Cantabrian Zone (N Spain).

taking advantage of the deserved homage that both of them are honoured with the publication of the current Spanish Journal of Palaeontology volume.

\section{PALAEOBIOGEOGRAPHY}

Understanding the palaeobiogeographical trends of the genera and species considered here is markedly hampered by the specialized character of their favoured reef or perireef environments, the usual scarcity of collections and the very scattered, often poorly contrasted observations. The peri-Gondwanan Perunica area was apparently an active evolutionary focus from which Teichertina radiated later along the Gondwana margin from Iberia to Australia. For example, the first known Teichertina species, T. minax Havlíček, 1977 and T. polyformis Havlíček, 1977 probably evolved according to Johnson (1972) from the long-lived Silurian-Lower Devonian Dicoelosia Bohemian lineage in the Prague basin area during the Early Devonian Zlichovian stage (early Emsian). The progressive closure of the Rheic
Ocean during the Middle Devonian would also allow a pathway for peri-Laurentian, Uralian migration, that could lead to the Teichertina arrival to Alaska (Teichertina sp., west-central Alaska Cheeneetnuk Lst, R.B. Blodgett, pers. comm., july 2017) and to the Cordilleran Nevada region (T. americana Johnson, 1970) during the Eifelian (Fig. 2). But it is more probable that the Teichertina sp was a transported element from northeastern Asia that reached Laurentia via Alaskan accreted terranes and dispersed later to Nevada, because the taxon is not known from western Canada or elsewehere in the north-American craton.

A more problematic migration route is that of Teichertina cf. peregrina Zhang, 1985, a similar form to the Nevada species which reached during the Eifelian the western Nei Monggol in northern China where (Fig. 2).

During the Givetian the climax of Teichertina evolution was reached. Teichertina peregrina Havlíček, 1977 occurs in the area of Moravia in Perunica, and a closely related form, $T$. cf. peregrina, is found in the middle Givetian of the Spanish Cantabrian region (see below). On the other hand, the Uralian migratory pathway allowed perhaps the occurrence of two poorly documented forms of Teichertina 
found in the Siberian block, Teichertina sp., cited and figured by Johnson (1972) from lower Givetian material of R.E. Alekseeva's from the Cherskii Range, and a Givetian age T. sibirica, cited by Johnson (1970) from NE Russia according to a correlation chart he observed that was composed by R.E. Alekseeva and A.L. Sidachenko, but for which he knew of no formal paper in which it was named or illustrated. During Givetian-Frasnian time interval a new species T. fitzroyensis Veevers, 1959, and a close form, $T$. cf. fitzroyensis (see below) spread over an extensive area covering northern Iberia (mid Givetian), central Nevada (late Givetian) and northwestern Australia (Frasnian). Afterwards the Teichertina lineage became extinct (Fig. 2).
Likewise the earliest known Costisorthis species, $C$. occlusa (Barrande, 1848) is a Pragian form coming from Bohemia, in Perunica. The genus migrated later to Baltica taking advantage of the narrowing of the Rheic Ocean. C. canalicula (Schnur, 1851) spread to Germany (mid Eifelian) and Poland (late Eifelian-early Givetian). The genus also moved southwards to the Spanish Cantabrian region, where the youngest Costisorthis, C. lisae nov. sp. (see below) occurs in the middle Givetian (Fig. 2). The occurrence of $C$. canalicula in the Emsian of the Bathurst Island, Arctic Canadian (Walmsley \& Boucot, 1975, p. 61) has not been confirmed to our knowledge.

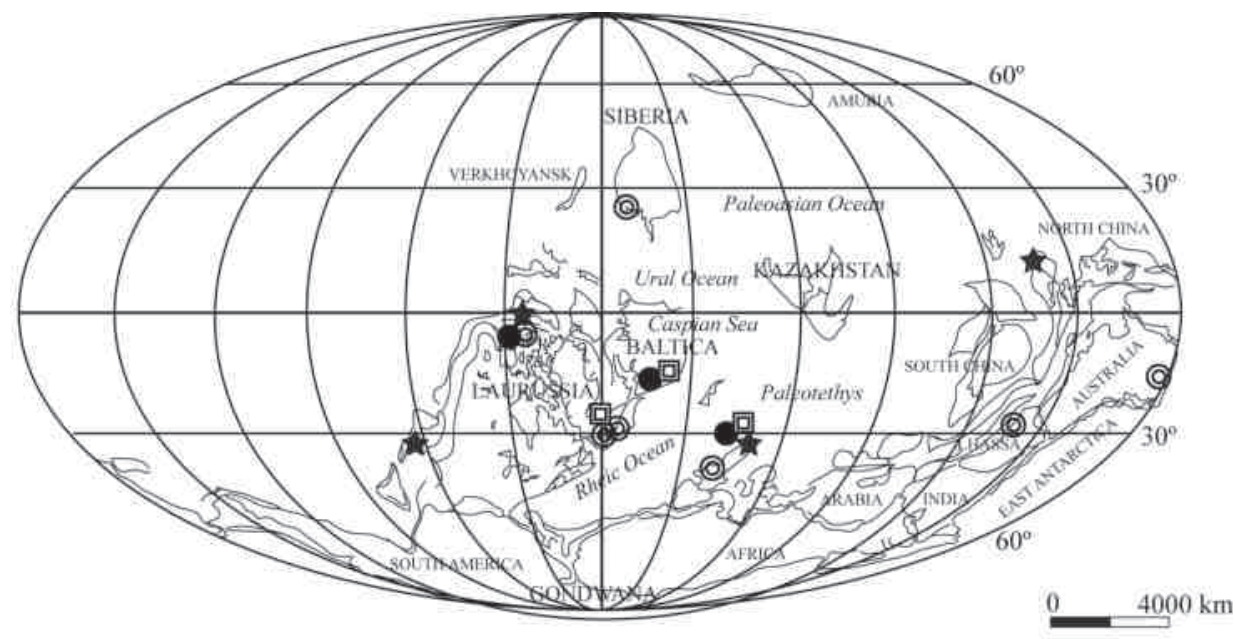

Early-Middle Devonian (Pragian, Emsian, Eifelian)

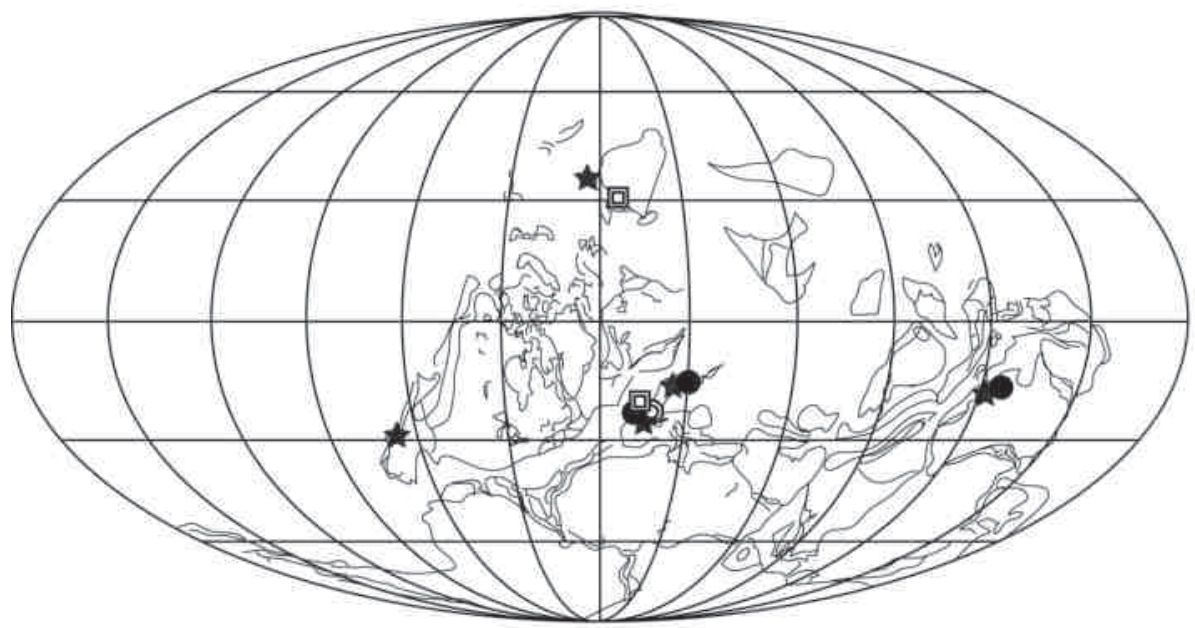

Givetian-Frasnian

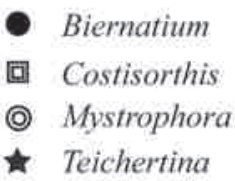

Figure 2. Palaeogeographical setting of the studied species during two Devonian time intervals, Lochkovian-Eifelian (above), and Givetian-Frasnian (below). Palaeogeographical maps modified from Kiessling et al. (1999) and Golonka (2002), simplified. 
Once again, the origin of Biernatium seems centered in Bohemia, where the oldest species Biernatium simplicior (Barrande, 1879) (cf. Havliček, 1977) occurs in the Pragian. The Uralian migratory pathway allowed the coeval occurrence of the species B. costatulum (Lenz, 1977) in the Royal Creek section of northwestern Canada. This form prolonged its upward range into the Zlichovian (lower Emsian) of the Northwest Territories of western Canada where it is known in the Delorme Formation (Perry, 1984). The approaching proximity to Baltica led to the distribution of the type species of the genus, B. fallax (Gürich, 1896) during the uppermost Eifelian-Givetian interval from Moravia (čelechovice na Hané) to Poland (Holy Cross Mts region). References to Burmese Biernatium occurrences are quite doubtful and they are for the moment rejected here (see below). A new Biernatium branch, represented by the species $B$. sucoi nov. sp. (see below) settled in the Spanish Cantabrian region during the middle Givetian. This lineage gave way finally to the Frasnian Cantabrian species Biernatium sp. 2 (see below) and further east, along to the northern Gondwana margin, to the mid to late? Frasnian Australian B. emanuelensis (Veevers, 1959) (Fig. 2).

The origin and palaeobiogeographical distribution trends of Mystrophora are difficult to discern. The earliest known forms are M. garraensis Lenz \& Johnson, 1985, from the upper Lochkovian or lowermost Pragian of the Wellington area in New South Wales (southeastern Australia), M. arctica Lenz, 1977, from the Zlichovian of the Road River Fm., northwestern Canada, and the Delorme Fm. in the Northwest Territories of Canada, and Mystrophora ? asiatica (Alekseeva in Alekseeva et al., 2006), from the lower Emsian of Mongol-Okhotsk area of the Siberian block. The type species of the genus, $M$. areola (Quenstedt, 1871) has been cited in the Eifelian over a large area including Germany, Brittany (France), and Padaukpin (Burma). The last representatives of the genus were, respectively, Mystrophora sp., from the TroisFontaines Fm. of the Givetian of Belgium (J. Godefroid in Godefroid \& Mottequin, 2005), and Mystrophora sp., from the lowermost middle Givetian of the Cantabrian region (see below) (Fig. 2). The above reference list does not include neither M. deshayesi, cited by Maillieux (1936), because it lacks a cruralium and has been chosen as the type species of Monelasmina, nor Mystrophora baylei, cited by Renaud (1942), because it belongs to Skenidium or Skenidioides.

\section{SYSTEMATICS}

Morphological and anatomical terms used herein are mainly after Williams \& Brunton (1997) and Harper (2000). The studied material is housed in the Geology Department Museum, University of Oviedo (provisional prefixed numbers, DPO).
Dalmanellacean costellate patterns are described after Bancroft's $(1928,1945)$ system, and remarks by Williams \& Wright (1963), Kemežys (1968) and Havlíček (1977) (Fig. 3). In short, the first-formed radial ribs on the external surface of shell are named primary costae (including the first dorsal pair; however see Kemežys, 1968). Ribs originating later than primary costae by division and/or insertion are named costellae (first-order, second-order costellae, and so on). The paired primaries are indicated by correlative Arabic numerals $(1,2,3 \ldots)$ and an unpaired central primary costa by letter M (median). Sectors defined by each pair of costae and close or derived costellae are designed by correlative Roman numerals (I, II, III...) (Fig. 3). In species description, formulas are given in the shortened form proposed by Bancroft (1945) in which only the terminal secondary ribs are outlined. Formulas can embrace all sectors but usually the first I-IV (plus the M) sectors will be enough to single out taxa. Bilateral

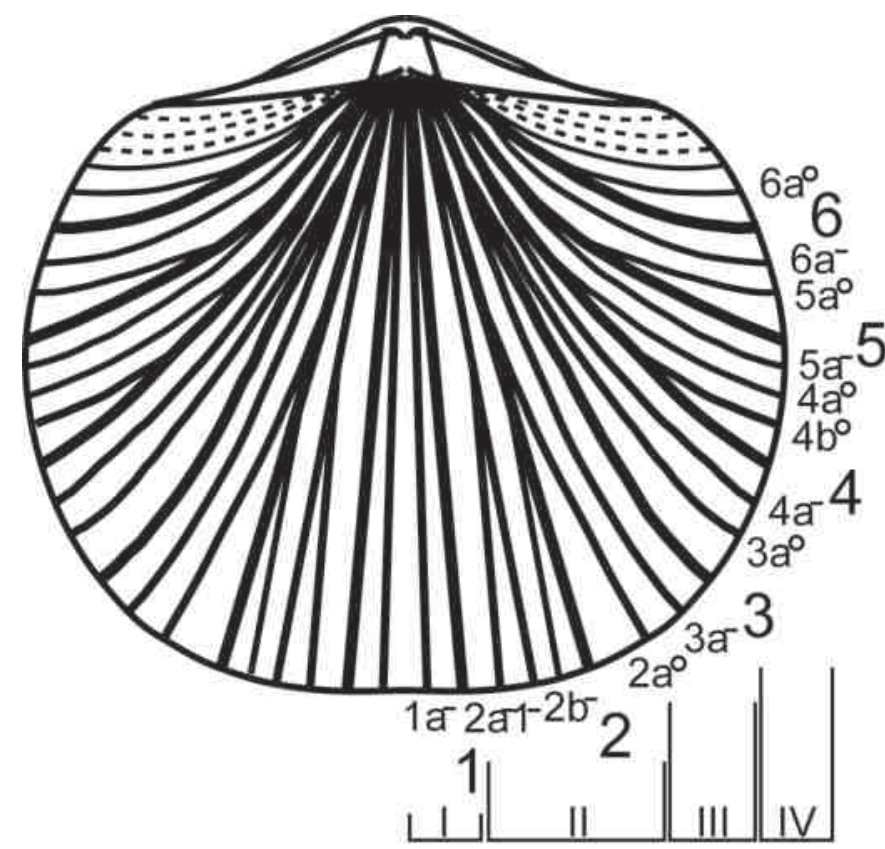

Figure 3. Bancroft's (1945) notational system for dalmanellacean radial ornament. Dorsal view of a complete, idealized dalmanellacean shell. Bold great numerals (1-6): notation of primary costae. Small numerals: notation of secondary costellae (1 $\mathrm{a}^{-}$to $6 \mathrm{a}^{-}$: first-order secondaries; $2 \mathrm{a}^{-1}$ : second-order secondary). Minus superindex (-) indicates internal costellae (radial elements that split off from the internal sides of parental ribs). Small circle superindex $\left(^{\circ}\right)$ symbol defines external costellae (radial elements that split off from the external sides of parental ribs). Roman numerals: Ornament sectors; sectors would embrace each primary costae and its derived secondaries, i.e. sector IV, comprises four elements, $4 \mathrm{a}^{-}, 4,4 \mathrm{~b}^{\circ}$, and $4 \mathrm{a}^{\circ}$. Dashed lines: undifferentiated posterolateral costae and costellae. 
symmetry will give way to an exact, mirror image, representation on both sides of shell, but exceptions (statistically meaningless, after Williams \& Wright, 1963) are frequent and one or more secondary ribs can miss on one side of shell. Asymmetric elements could be represented in formulas by brackets.

All the species studied below display the so-called isorthoid ornament system, i.e. the characterized by the occurrence of an unpaired median costa $(M)$ on the ventral valve, and a sub-median pair of primary costae 1 on the dorsal valve.

Order ORTHIDA Schuchert \& Cooper, 1932

Suborder DALMANELLIDINA Moore, 1952

Superfamily Dalmanelloidea Schuchert, 1913

Family Dalmanellidae Schuchert, 1913

Subfamily Isorthinae Schuchert \& Cooper, 1931

Genus Costisorthis Havlíček, 1974

Remarks. The Isorthinae Schuchert \& Cooper, 1931 is a long-lived dalmanelloid subfamily extending from lowermost Silurian to the Middle Devonian. It is also a paleogeographically widely distributed taxon unrecorded in the Malvinokaffric Realm (Walmsley \& Boucot, 1975). The genotype of the subfamily, Isorthis Kozłowski, 1929, has been subdivided into several subgenera, further promoted in part to generic rank and even resettled into closely related subfamilies. The youngest known isorthine species is the Cantabrian Costisorthis lisae nov. sp. from the Candás Formation, Faunal Interval 21, Polygnathus rhenanus/P. varcus zone (García-López, 1986; GarcíaLópez \& Sanz-López, 2002a), middle Givetian. Dalmanella sibirica Khalfin, 1937, from the upper Givetian of Siberia (Fig. 2), which Walmsley \& Boucot (1975) referred to Isorthis (Tyersella), could also belong to Costisorthis but the available original illustration and description of the species are too poor to draw a definite conclusion. Isorthis canalicula (Schnur, 1851), from the upper Eifelian (or lower Givetian) of the Holy Cross Mountains, Poland (Fig. 2), which Walmsley \& Boucot $(1975$, p. 60) and Halamski (2009) referred likewise to Tyersella has been later interpreted as Costisorthis by Havlíček (1977, p. 193, with the mistaken spelling "canaliculata") based on the distinctive semi-fascicostellate, plicate radial ornamentation.

Costisorthis lisae nov. sp. (Figs 1-5, 6a1-61)

v. 1996 Tyersella nov. sp. A, García-Alcalde, fig. 3.
Derivatio nominis. Species dedicated in honour to Dra. Maria Luisa Martínez-Chacón, familiarly known by their friends as "Lis", unrivalled and quasi-eternal editor of the Revista Española de Paleontología (currently Spanish Journal of Palaeontology), in her retirement as Professor of Palaeontology in the University of Oviedo (Spain).

Locus and stratum typicum. Ancient Espinedo Quarry, near Espinedo hamlet, Cornellana, Salas, Asturias province, $\mathrm{N}$ Spain, ca. one hundred of meters north of N-634 road, about 100 m northeast of St. Ramón Chapel (Figs 1, 4). Lower part of the Candás Formation, dark argillaceous limestones interbedded with light coralline limestones with abundant Davidsonia verneuili, Locality I-114 (ca. E-10 of García-López, 1986), Faunal Interval 21, Polygnathus rhenanus/P. varcus zone, middle Givetian (Fig. 5).

Material. Several complete, well preserved shells, isolated dorsal and ventral valves, and internal dorsal moulds. Holotype DPO 48164 (Fig. 6), twelve paratypes DPO 48161-48162, 48167-48172, 48175, 48178-48180 (Fig. 6), and nineteen topotypes, DPO 48163, 4816548166, 48173-48174, 48176-48177, 48181-48192 from the stratotype.

Diagnosis. A species of Costisorthis with dorsal and ventral plicae weaker than usual in the genus, sometimes reduced to bundles of fine costellae standing up weakly from shell surface, a well-developed dorsal sulcus, and low, curved, orthocline/apsacline interareas. Dorsal muscle field strongly bounded by furrowed, rounded ridges, median dorsal septum strong, subangular with a distinctive trifid ending, posterior dorsal adductor scars wrinkled by anterolaterally directed narrow folds.

Description. Shell of medium size (greatest length, $L$ : $19.8 \mathrm{~mm}$ ), subrectangular to transversely suboval (average width/Length, $w / L: 1.1$, from eight measurements), thick (average thickness/Length, $t / L: 0.44$, from seven measurements), subequally biconvex, greatest convexity in the umbonal region, hinge-line straight shorter than maximum width of shell that is at mid-length (average of the hinge width, $h w: 60 \%$ of the greatest width, from fifteen measurements), anterior commissure crenulate and sulcate, cardinal and antero-lateral angles rounded (average of cardinal angle, $\beta: 148^{\circ}$, from nine measurements) (Table 1). Growth lamellae numerous, irregularly distributed, sometimes slightly imbricated. Ventral valve slightly longer and more convex than dorsal valve, beak rounded, extending beyond the hinge-line, apical angle obtuse (average of apical angle, $\alpha: 111^{\circ}$, from fifteen measurements) (Table 1), beak sub-erect to strongly curved, ventral interarea relatively well-developed, curved, apsacline, transversely grooved, delthyrium small, triangular, open, sometimes concealed by the dorsal beak; 


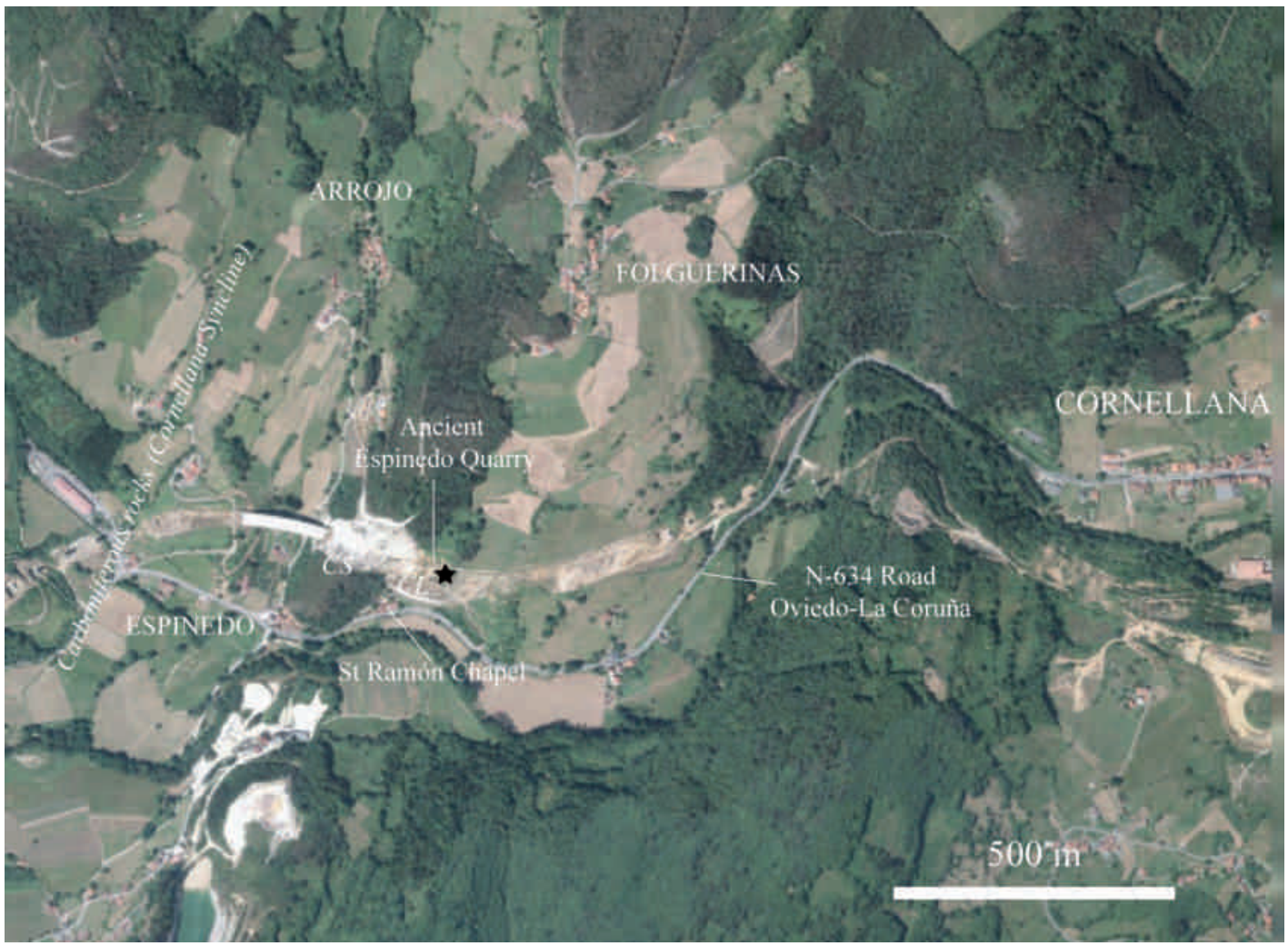

Figure 4. Black star: locus typicus (type locality) of Costisorthis lisae nov. sp., locality I-114. Aerial photo (oriented North) and coordinates SIGPAC (Asturias), 4324'34”N, 6¹0'45.23"W. Ancient Espinedo Quarry, near Espinedo hamlet (Cornellana, Salas, Asturias province), ca. $100 \mathrm{~m} \mathrm{NE} \mathrm{St.}$ Ramón Chapel. CL: Candás Limestone Formation. CS: Candás Sandstone Formation.

Table 1. Costisorthis lisae nov. sp. Measurements of the best preserved specimens. L: Length (in mm); w: width (in mm); t: thickness (in mm); hw: hinge width regarding greatest width shell (percent); $\alpha$ : apical angle (sexagesimal degrees); $\beta$ : cardinal angle (sexagesimal degrees); wmax: shell width regarding shell length (percent); dsw: dorsal sulcus width regarding maximum shell width (percent); ba: brachiophore angle (sexagesimal degrees).

\begin{tabular}{llllllllllll} 
DPO & $\mathrm{L}$ & $\mathrm{w}$ & $\mathrm{t}$ & $\mathrm{w} / \mathrm{L}$ & $\mathrm{t} / \mathrm{L}$ & $\mathrm{hw}$ & $\mathrm{a}$ & $\mathrm{b}$ & $\mathrm{wmax}$ & $\mathrm{dsw}$ & $\mathrm{ba}$ \\
\hline Holotype 48164 & 17.7 & 20.9 & 8.3 & 1.18 & 0.47 & 63 & 104 & 155 & 49 & 35 & - \\
Paratype 48161 & 19.7 & 21.5 & 10.1 & 1.08 & 0.51 & 50 & 108 & 149 & 56 & - & - \\
Paratype 48162 & 19.8 & 21.5 & 10.1 & 1.08 & 0.51 & 60 & 118 & 141 & 52 & 35 & - \\
Paratype 48167 & 11.9 & 14 & 5.3 & 1.18 & 0.44 & 70 & 109 & 150 & 50 & 42 & - \\
Paratype 48168 & 12.8 & - & 4.8 & - & 0.37 & 69 & 105 & 151 & 42 & 48 & - \\
Paratype 48169 & - & 23 & - & - & - & 59 & - & - & - & - & 76 \\
Paratype 48170 & - & 21.3 & - & - & - & 56 & - & - & - & - & 112 \\
Paratype 48171 & - & 20.2 & - & - & - & 62 & - & - & - & - & 95 \\
Paratype 48172 & - & - & - & - & - & 56 & - & - & - & - & 93 \\
Paratype 48175 & - & 18 & - & - & - & 57 & - & - & - & - & 85 \\
Paratype 48178 & 18.2 & & 19.5 & - & 1.07 & - & - & - & - & - & \\
Topotype 48163 & 19.7 & 21.5 & 8.5 & 1.09 & 0.43 & 55 & 101 & 147 & 53 & - & - \\
Topotype 48165 & 19.4 & 19.7 & 7.7 & 1.01 & 0.40 & 58 & 115 & 148 & 49 & 42 & - \\
Topotype 48166 & 12.9 & 14.8 & - & 1.15 & - & 70 & 125 & 140 & 52 & - & - \\
Topotype 48173 & - & 18.9 & - & - & - & 63 & & & & & 92 \\
Topotype 48174 & - & 18 & - & - & - & - & - & - & - & - & - \\
Average & $\mathbf{1 6 . 9}$ & $\mathbf{1 9 . 2}$ & $\mathbf{7 . 7}$ & $\mathbf{1 . 1}$ & $\mathbf{0 . 4 4}$ & $\mathbf{6 0}$ & $\mathbf{1 1 1}$ & $\mathbf{1 4 8}$ & $\mathbf{5 1}$ & $\mathbf{4 0}$ & 92
\end{tabular}


median fold distinct, originating at beak and extending to anterior of valve, axial part of fold accentuated by the occurrence of a weak plica composed by the ribs of the sector M, sometimes accompanied by other less pronounced plicae in sectors I of valve, formed by narrow bundles of primary costae 1 and derived costellae. Dorsal valve with a beak that is smaller than ventral beak, dorsal interarea shorter than ventral interarea, planar, orthocline; nothothyrium small, triangular, filled by the cardinal process; a deep and broad median sulcus extends from the beak to the sulcate anterior commissure where it is about $40 \%$ (average from six measurements) (Table 1) as large as the greatest width.
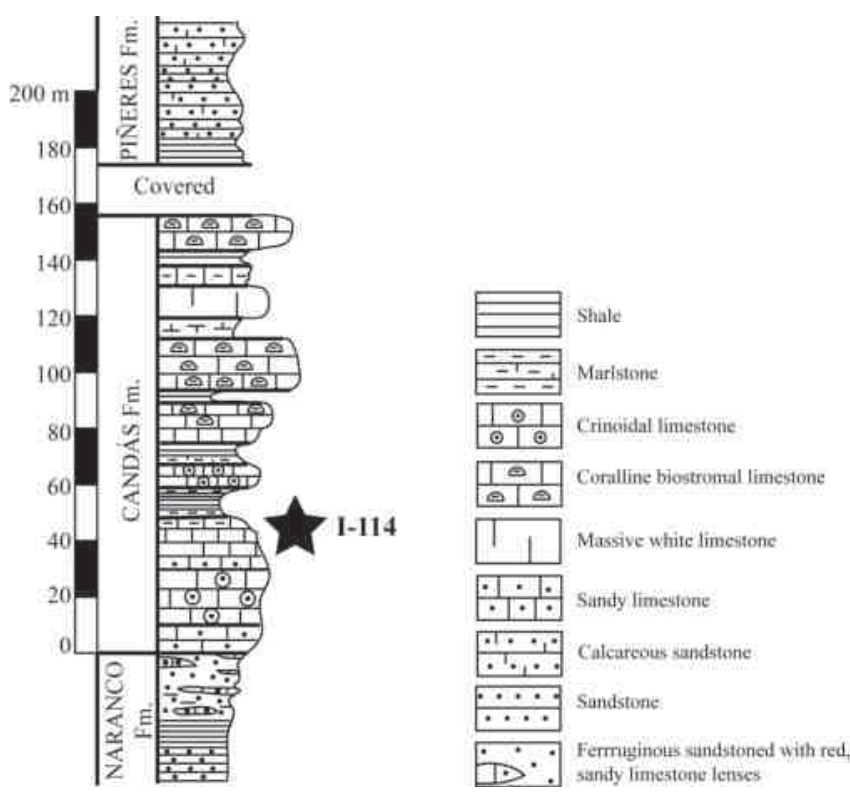

Figure 5. Costisorthis lisae nov. sp. Stratigraphic column of the locus typicus. After García-López (1986), modified and completed. Fm. = Formation.

Radial ornament composed of six to seven primary costae slightly stronger than secondaries, costellae numerous, fine, subangular, growing by dichotomy along three or four levels of division, central costae and costellae straight, lateral ones strongly bending abaxially to intersect the margins of interareas in a heterorthoid-like way (Fig. $6 \mathrm{c} 1$ ), interspaces as wide as costellae, 5-6 ribs per $2 \mathrm{~mm}$ at a distance of ca. $15 \mathrm{~mm}$ from the beak; mid ventral fold composed in adult forms by a strong median costa $\mathrm{M}$ and ca. fifteen another radial elements, axial line accentuated by a subangular low plica composed by costa $\mathrm{M}$ and derived secondary costellae $\mathrm{Ma}^{\circ} 1^{\circ}, \mathrm{Mb}^{\circ} 1^{\circ}, \mathrm{Mc}^{\circ}$; at each side of the median plica there sometimes occurs weaker plications composed by the primary costae 1 and derived secondary costellae (Figs 6c1, 6e2). Sectors II and III may also bear occasionally marked costellae bundles that stand slightly out from the valve surface. The more usual early ephebic ornament formula (dorsal valve) is:

Sectors I to IV: 1a-1 $1 \mathrm{a}^{-} ; 2 \mathrm{a}^{-}, 2 \mathrm{~b}^{-} ; 3 \mathrm{a}^{-1}, 3 \mathrm{a}^{\circ} ; 4 \mathrm{a}^{-}, 4 \mathrm{a}^{\circ}$, $4 b^{\circ} \ldots$ with secondaries internal and external developed from sectors III to posterolateral sectors.

Interior of ventral valve. Delthyrial cavity deep with a strong ventral callist horizontally grooved (Fig. 6j); cardinal teeth well-developed, long and narrow, diverging dorsolaterally, supported by short and thick dental plates that merge anteriorly with low, rounded ridges bounding the muscle field; crural fossettes short and deep (Fig. 6j), welldeveloped post-dental denticular cavities to accommodate the outer socket ridges; muscle field bilobed, relatively short, less than half the valve length, divided by a large, planar, median longitudinal ridge, one-quarter to one-third the width the muscle field, raised and widened anteriorly to end in a high steep slope to the valve floor (Figs 6e1, 6h, 6j); adductor scars, narrow, elongate, oval, resting partially on the median ridge and partially lateral to it; adductor scars completely encircled by pyriform, slightly divergent diductor scars; the diductor impressions end anteriorly in wide, divergent vascula media trunks; vascular system lemniscate.

Interior of dorsal valve. Cardinal process short, small, bilobed to trilobed, resting on a thick nothothyrial platform. Brachiophores well-developed, with strong, sub-vertical brachiophore bases that diverge anteriorly about $90^{\circ}$ (average $b \alpha: 92^{\circ}$, from six measurements) (Table 1), the brachiophores bound postero-laterally deep, triangular dental sockets excavated on socket pads with no fulcral plates, outer socket ridges, thin, long, parallel to the interarea margin; muscle field petaloid, confined to posterior half of valve, bounded by strong, rounded ridges laterally and antero-laterally furrowed to channel external myaria and pre-myaria vascular trunks (Figs 6d1, 6k1, 61); median dorsal septum starting at the base of the nothothyrial platform, high, relatively large, subangular, with a strongly developed, trifid, globose ending, furrowed to channel the median vascular trunks (Figs 6k1, 61); quadripartite muscle field, divided transversally by ridges normal to median septum; posterior adductor scars triangular, confined to the nothothyrial cavity, wrinkled by 2-3 antero-laterally directed, narrow folds (Figs 6k1, 61); anterior adductors pyriform, greater than posterior, unornamented; vascular system weakly impressed, lemniscate.

Discussion. C. lisae nov. sp. departs from both the type species of Costisorthis, C. occlusa (Barrande, 1848), and C. canalicula (Schnur, 1851) in the less developed plicae on the shell. Moreover, the two latter species are less sulcate and the postero-lateral costellae do not intersect the cardinal area margins as in C. lisae nov. sp. Dalmanella sibirica Khalfin, 1937 is also less sulcate than $C$. lisae nov. sp. and has a markedly subquadrate outline. 


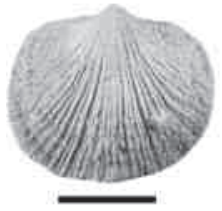

a1

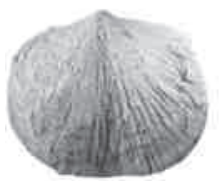

a2

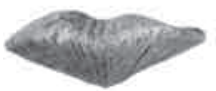

a3

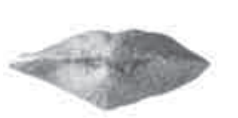

a4

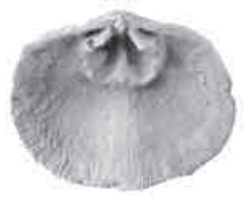

$\mathrm{f}$

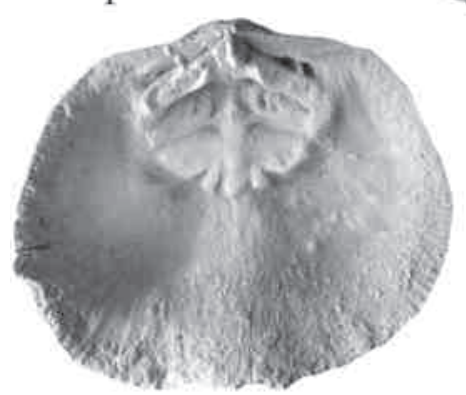

k1

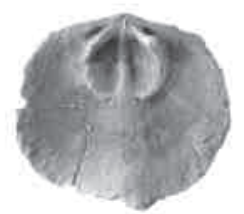

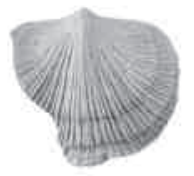

b1

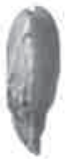

b2

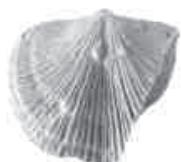

b3

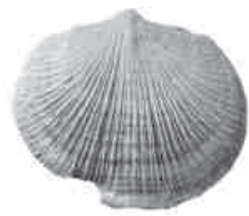

c1

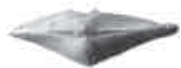

b4

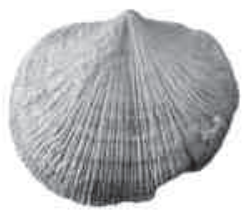

c2

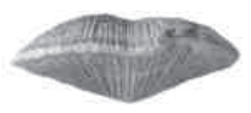

c3
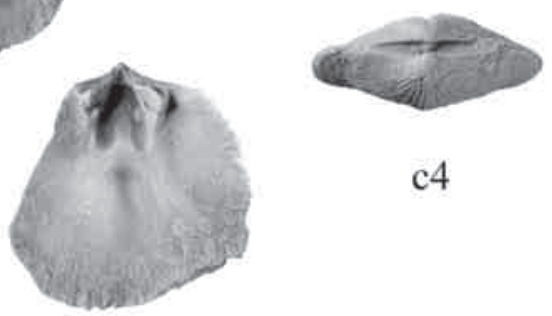

$\mathrm{h}$

c4

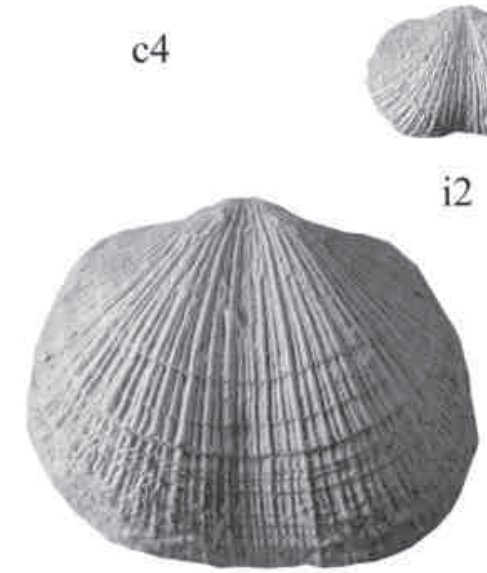

k2

i2
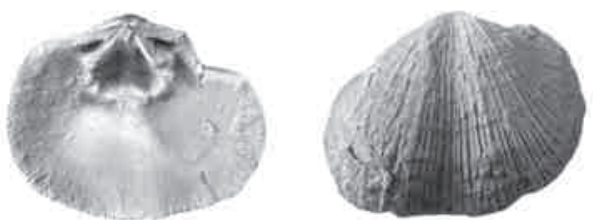

d1

d2

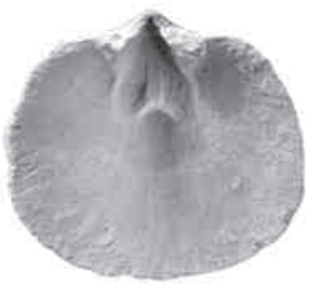

el

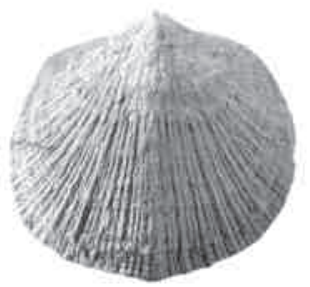

e2

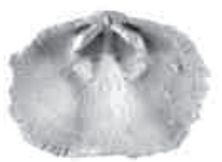

i1
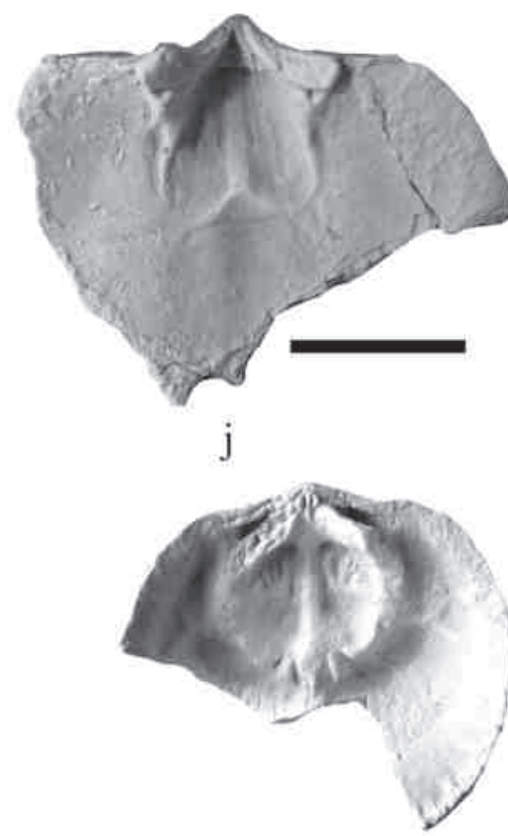

1

Figure 6. Costisorthis lisae nov. sp. from the stratotype, Candás Fm., middle Givetian. a1-a5) Paratype DPO 48167, ventral, dorsal, anterior, posterior, and lateral views. b1-b4) Paratype DPO 48168, ventral, lateral, dorsal, and posterior views. c1-c5) Holotype DPO 48164, ventral, dorsal, anterior, posterior, and lateral, views of a slightly damaged shell. d1-d2) DPO 48169, dorsal valve, internal and external views. e1-e2) Paratype DPO 48178, ventral valve, internal and external views. f) Paratype DPO 48171, dorsal valve, internal view. g) Paratype 48173, dorsal valve, internal view. h) Paratype DPO 48180, interior of ventral valve. i1-i2) Paratype DPO 48175, dorsal valve, internal and external views. j) Paratype DPO 48179, interior of an incomplete ventral valve. k1-k2) Paratype DPO 48170, dorsal valve, internal and external views. I) Paratype DPO 48172, dorsal valve, interior of an incomplete specimen. Scale bars $=10 \mathrm{~mm}$ (large scale bar corresponds to Figs $6 \mathrm{~h}, 6 \mathrm{j}-61$ ).

Family Dicoelosiidae Cloud, 1948

Genus Teichertina Veevers, 1959

Diagnosis. Small, bisulcate, spiriferoid-like shells, strongly ventri-biconvex, wider than long, subpentagonal, with weakly emarginated outline, greatest width at hingeline, cardinal angles acute, cardinal margins mucronate, slightly drawn out in pointed short ears, sub-median regions of shell slightly inflated, trending to bilobation; ornamentation usually parvicostellate, primary costae fine to coarse, ventral valve hemipyramidal; interior of ventral valve with very short, vestigial dental plates, delthyrium provided by a small apical internal, concave plate; muscle field sub-apical, muscle scars undifferentiated. Interior of dorsal valve with a bilobed cardinal process, 
shaft continuous with a long median septum, ancillary struts present; brachiophores long, blade-like, hooked proximally; dental sockets supported by fulcral plates; muscle field quadripartite, narrowing forwards, bounded laterally by strong ridges, extending along the valve floor almost to anterior margin; margins of valve strongly grooved defining peripheral, rounded ridges interlocking with similar ridges on internal ventral valve margins.

Discussion. Johnson (1972) argued for the origin of Teichertina from Dicoelosia King, 1850 and his conclusions are generally accepted. Both genera differ however considerably in size, outline, lateral profile, and internal structures. The oldest Teichertina species are Teichertina polyformis Havlíček, 1977 and Teichertina minax Havlíček, 1977 from the Pragian of Bohemia. Both species represent a particular evolutionary trend in the ornament characterized by the occurrence of strong radial ribs superimposed to very fine, sometimes almost imperceptible costellae. This trend has kept in the Bohemian Middle Devonian T. peregrina Havlíček, 1977 and in the Spanish T. cf. peregrina and co-exists with the parvicostellate model common in T. americana Johnson, 1970, from the Eifelian of Nevada, T. cf. americana cited by Zhang (1985) from the Eifelian of Nei Mongol, China, T. fitzroyensis Veevers, 1959, from the uppermost Givetian of Nevada to the upper (?) Frasnian of Australia, and $T$. cf. fitzroyensis, from the middle Givetian of N Spain (Fig. 2).

Teichertina cf. fitzroyensis Veevers, 1959

(Figs 1, 2, 8a1-8a5, 8c1-8c6, 11)

pars v. 1995 Teichertina sp., García-Alcalde, fig. 7

pars v. 1996 Teichertina sp., García-Alcalde, fig. 3.

Material. Three complete shells, one of which is DPO 47357 a well-preserved complete shell, from Las Pozas de Santa Eugenia, W Aviados (La Vecilla, León), lower tiers of the Portilla Fm., locality K-79 (Z-35) (Figs 1, 11), middle Givetian, and two other shells, DPO 47358-47359 the latter one crushed, from Sierra de Las Traviesas, N Cermoño, (Salas, Asturias), Candás Fm., locality I-110 (Figs 1, 7), middle Givetian.

Description. Small spiriferoid-like shell (maximum length: $5 \mathrm{~mm})$, strongly biconvex, thick $(t / L: 0.88)$, subpentagonal, wider than long $(w / L: 1.47)$, with faintly emarginated outline, bisulcate, with a weak ventral sulcus and a sharp, deep, dorsal sulcus; greatest width at hingeline, cardinal angles acute, cardinal margins drawn out in short, pointed ears (Figs 8a1-8a2); sub-median regions of both valves inflated, with a trend to bilobation, especially marked in the dorsal valve, with lobes defined between the sulcus base and the planar to concave posterolateral

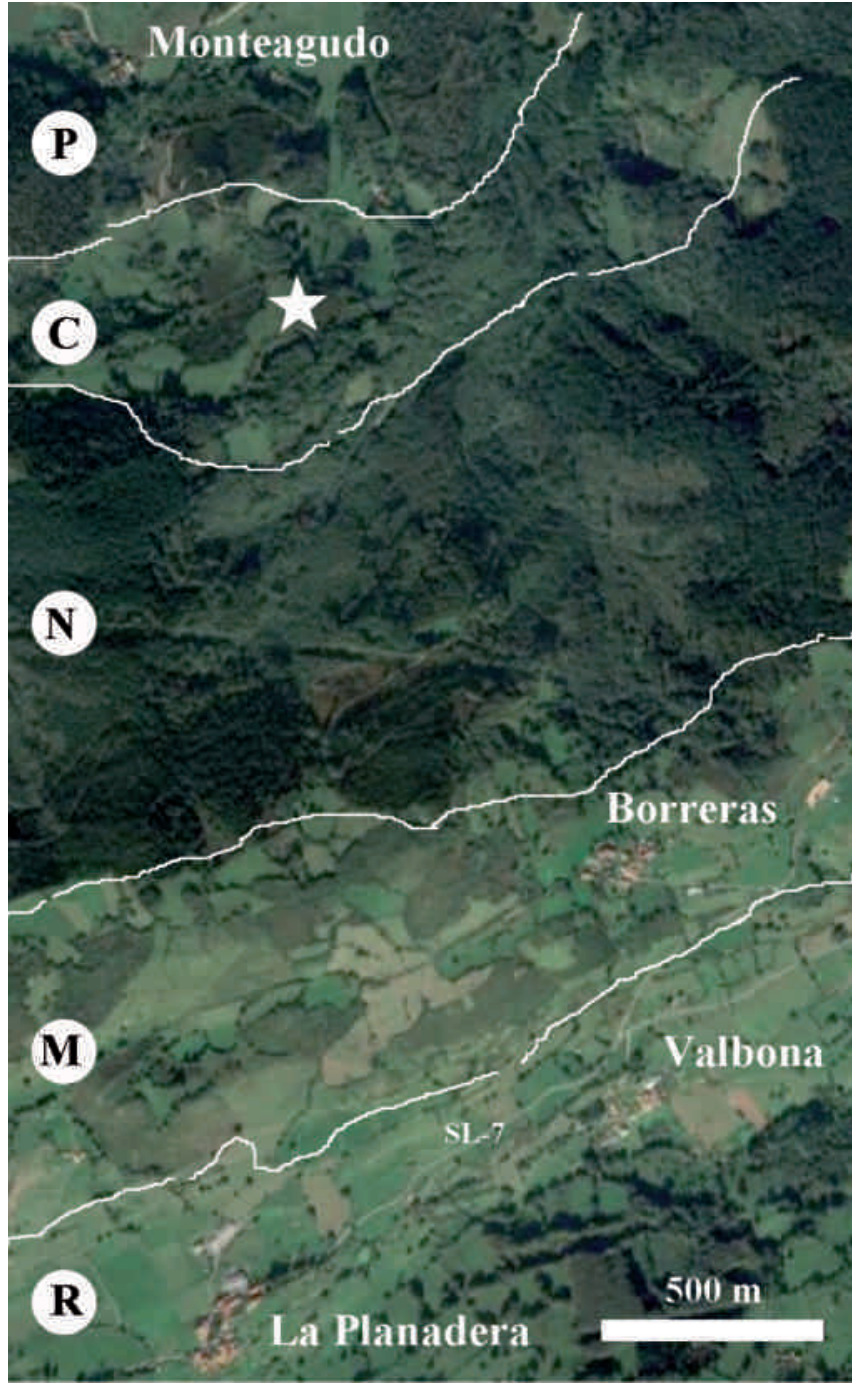

Figure 7. White star: Locality I-110 of Teichertina cf. fitzroyensis (Veevers, 1959), North La Planadera hamlet (Cornellana, Salas, province of Asturias). Irregular white lines represent rough geological contacts. $C$ : Candás Fm.; $M$ : Moniello Fm.; $N$ : Naranco Fm.; $P$ : Piñeres Fm.; R: Rañeces Group. Google Maps, oriented north.

areas of valve (Figs 8a3, 8c5); ventral valve lobation much weaker than dorsal due to weaker ventral valve sulcus and postero-lateral flattening; anterior commissure clearly sulcate, semi-lobate, and slightly emarginated (Figs 8a1, $8 \mathrm{c} 2,8 \mathrm{c} 5$ ), lateral commissures straight. Shell structure is indiscernible in the specimens at hand. Ventral valve hemipyramidal (Fig. 8c3), much longer than dorsal valve, lateral profile evenly convex, with the maximum convexity at umbo, umbo prominent and clearly projected behind the hinge-line, beak straight to weakly inclined, usually slightly twisted resulting in an asymmetrical-shaped shell (Figs 8c1-8c2, 8c6), apical angle largely obtuse (average $120^{\circ}$ ), interarea long (average $2.4 \mathrm{~mm}$ ), weakly concave, 
apsacline, transversely grooved, with sharp posterior margins, delthyrium narrow (one-sixth the width of the cardinal-hinge), open, with a short concave apical plate barely sunk in the delthyrial cavity; ventral valve median sulcus shallow to inconspicuous bounded laterally by subangular plicae which bear along their crests the primary costae of sectors I (Fig. 8a2), the sulcus begins at the beak and widens anteriorly to reach the anterior margin where it occupies ca. $32 \%$ of maximum width of shell. Dorsal valve shorter than ventral valve, lateral profile evenly convex with the maximum convexity at mid-length, interarea short, ca. one-sixth the ventral valve length, planar, grooved as in the ventral interarea, notothyrium narrow, open, filled by a small bilobed cardinal process, umbo small, beak minute; median sulcus sharply defined (Figs 8a1, 8c2) beginning at the beak and widening and deepening anteriorly to reach the shell margin where it meets with the ventral valve sulcus. Ornamentation parvicostellate, 6-7 primary costae pairs, defining among them large and concave sectors, each occupied by 4-5 very fine secondary costellae; costa $M$ weaker than neighbor primaries, running on ventral valve sulcus base (Fig. 8a2), the 3-4 first lateral primary costae pairs in both valves are situated on the crests of rounded plications (Figs 8a1-8a3). Growth lamellae imbricate, numerous and closely disposed near the shell margins, intersecting the radial ribs to form a characteristic meshlike pattern (Fig. 8a2). Judging from the successive growth stages defined by the growth lines, the young shells would be much more alate and spiriferoid than the adult. Internal characters are unknown.

Discussion. Teichertina cf. fitzroyensis is very close to the nominal species, but both the Australian and the Nevadan specimens of that species have more primary costae than the Spanish species. Teichertina americana Johnson, 1970 is also a closely related species, but it has a flat and catacline ventral interarea and its radial ornamentation is coarser than that of Teichertina cf. fitzroyensis.

Teichertina cf. peregrina Havlíček, 1977 (Figs 1, 2, 8b1-8b5, 9, 10)

pars v. 1995 Teichertina sp., García-Alcalde, fig. 7

pars v. 1996 Teichertina sp., García-Alcalde, fig. 3.

Material. One complete, well preserved shell DPO 47356, $3.36 \mathrm{~mm}$ long, $4.96 \mathrm{~mm}$ wide, $3.12 \mathrm{~mm}$ thick, from Huergas de Gordón, South La Pola de Gordón (province of León) (Figs 1, 9), Portilla Fm., level HUG-19/20 (Fig. 10), Faunal Interval 21, middle Givetian.

Description. Shell minute, transverse (w/L: 1.48), thick (t/L: 0.93), strongly ventri-biconvex, maximum convexity at umbones, outline spiriferoid, subpentagonal, greatest width at hinge, cardinal extremities weakly drawn out laterally in small, rounded ears, postero-lateral margins straight, antero-lateral sides rounded, cardinal angles slightly greater than $90^{\circ}$, shell bisulcate with the dorsal sulcus much deeper than ventral sulcus, anterior commissure weakly emarginated and sulcate, lateral commissures straight; in anterior view the shell shows a weak trend to bilobation because of the inflated sub-median parts of the dorsal valve, bounded by the dorsal sulcus and by strongly flattened to slightly depressed sides, and similar, although much less developed, ventral opposing parts. Ventral valve hemi-pyramidal, sub-pentagonal, umbo moderately drawn out posteriorly, beak small, inclined to sub-erect, apical angle strongly obtuse, interarea very high, half the greatest width, flattened, transversally grooved, steeply apsacline, almost catacline, with sharp posterior margins, delthyrium very narrow, one-seventh the hinge width, open, with a small apical plate barely sunken in the delthyrial chamber; median sulcus relatively large, very shallow which starts at beak and widens distally reaching the anterior margin where it is half the greatest width. Dorsal valve almost as long as the ventral valve, moderately convex, umbo small, beak as developed as the ventral beak, interarea short, flat, anacline, 3-4 times lower than ventral interarea, transversally grooved, nothothyrium open, narrow, filled by the cardinal process; median sulcus deep, relatively large, with a rounded bottom, starting at beak and widening and deepening distally to reach the anterior margin where it meets with the ventral valve sulcus (Figs 8b1-8b5). Ornamentation of thick, subangular, usually unbranched primary costae, separated by concave interspaces narrower than costae (Figs 8b1, 8b3, 8b5); a primary costa $\mathrm{M}$, stronger than the other primaries runs along the ventral sulcus base (Fig. 8b1); in both valves each costa of the pair 1 gives rise to one inner secondary rib more slender than the parent costa (Fig. 8b3); the folded radial ornamentation is superimposed on an exceedingly fine system of radial costellae that can be observed in the specimen at hand on the bottoms of the larger dorsal intercostal furrows. Shell covered by a fine system of crowded concentric filae, imbricate growth lamellae not observed. Interior of shell is unknown.

Discussion. Teichertina cf. peregrina is close to the nominal Bohemian species, but it is much smaller, with thicker lateral profile, less alate outline, and scarce or virtually no development of secondary ribs. T. fitzroyensis has a clearly parvicostellate ornament pattern, quite different to the costae of $T$. cf. peregrina. T. americana differs in its more alate outline, catacline ventral interarea, coarser concentric ornamentation, important development of secondary ribs, less developed costa $\mathrm{M}$, and lack of submedian secondary internal ribs. 


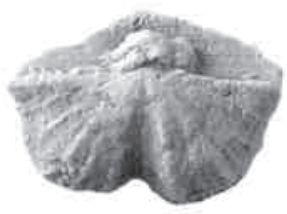

al

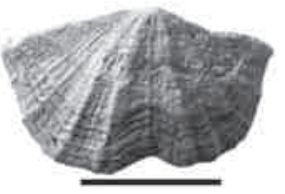

a2

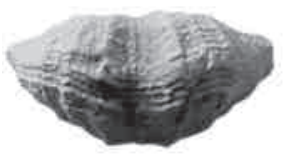

a3

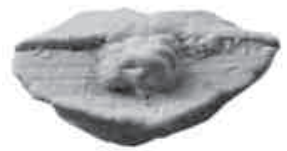

a4

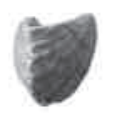

b4

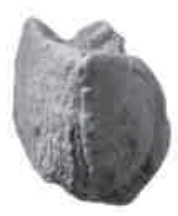

a5

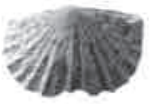

b1

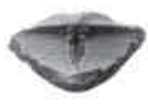

b2

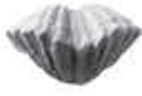

b3

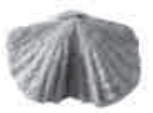

b5

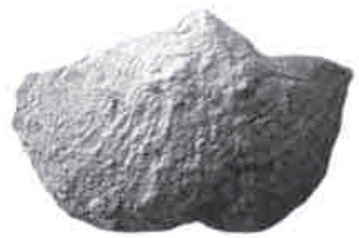

$\mathrm{cl}$

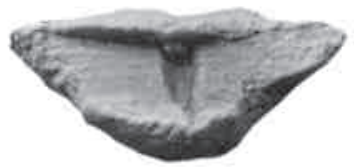

c4

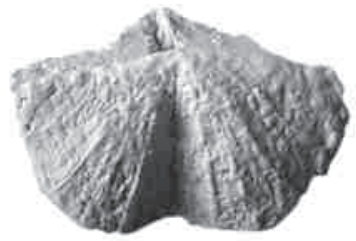

c2

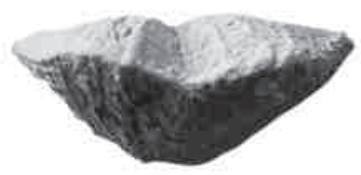

c5
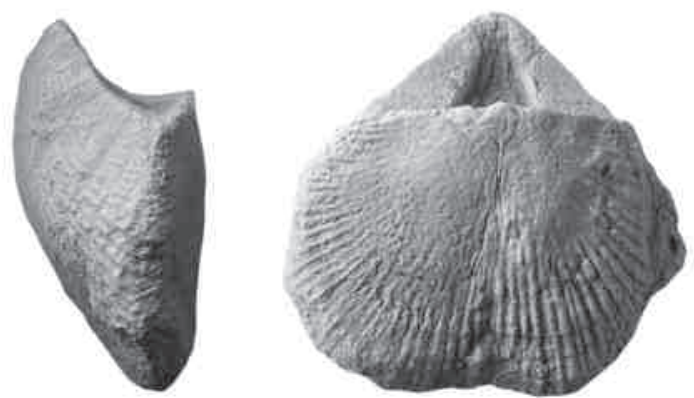

d2

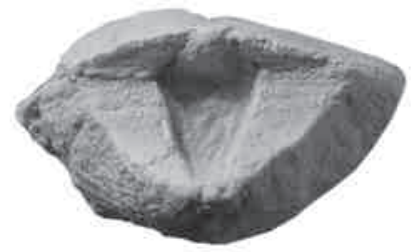

d4

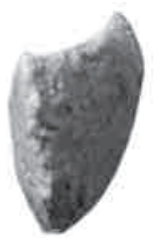

c3

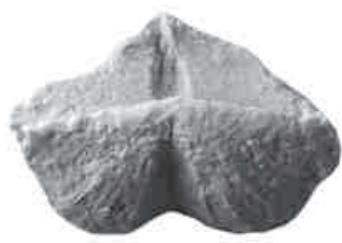

c6

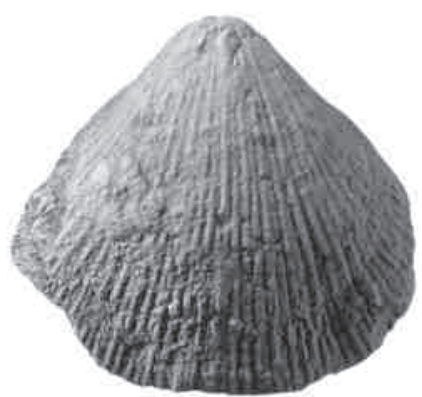

d3

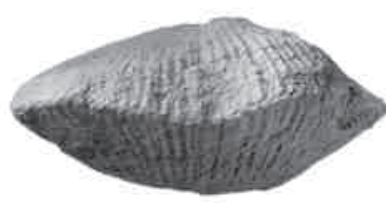

d5

Figure 8. a1-a5) Teichertina cf. fitzroyensis (Veevers, 1959), DPO 47357, dorsal, ventral, anterior, posterior, and lateral views. Las Pozas de Santa Eugenia (Asturias), locality K-79 (Z-35), middle Givetian. b1-b5) Teichertina cf. peregrina Havlíček, 1977, DPO 47356, ventral, posterior, anterior, lateral, and dorsal views. S Huergas de Gordón (León), locality HUG 19/20, middle Givetian. c1-c6) Teichertina cf. fitzroyensis (Veevers, 1959), DPO 47358, ventral, dorsal, lateral, posterior, anterior and postero-dorsal (to see the twisted ventral beak) views. Sierra de Las Traviesas, Cermoño, Salas (Asturias), locality I-110, middle Givetian. d1-d5) Mystrophora sp. DPO 47355, lateral, dorsal, ventral, posterior, and anterior views. South Huergas de Gordón (León), locality I-31, middle Givetian. Scale bar $=5 \mathrm{~mm}$.

Family Mystrophoridae Schuchert \& Cooper, 1931

Genus Mystrophora Kayser, 1871

Remarks. As indicated above, Mystrophora is a largely distributed taxon, both in time (Pragian to Givetian) and space (Europa, Burma, Australia, northwestern Canada). However some references to it must be rejected, i.e., Maillieux's (1936) reference to Mystrophora deshayesi because Rigaux's (1872) species lacks a true cruralium and has been chosen as the type of Monelasmina Cooper,
1955. Likewise Renaud's (1942, p. 38) reference to Mystrophora baylei must be rejected because the Rouault's (1846) species Orthis baylei belongs to the Superfamily Skenidioidea Kozłowski, 1929.

\section{Mystrophora $\mathrm{sp.}$}

(Figs 1, 2, 8d1-8d5, 9, 10)

v. 1979 Mystrophora areola, García-Alcalde (in García-Alcalde et al., p. 18). 
Descriptive remarks. The unique specimen at hand, a complete shell DPO 47355, comes from the section of Huergas de Gordón (province of León, N Spain) (Figs 1, 9), lower part of the Portilla Fm., unit A, level HUG 6/7, upper part, locality I-31, argillaceous limestones with intercalated dark marls and shales, Faunal Interval 21, Polygnathus rhenanus/P. varcus zone, middle Givetian (Fig. 10).

The specimen (Figs 8d1-8d5) is $12.5 \mathrm{~mm}$ long, 12.9 $\mathrm{mm}$ wide, and $6.4 \mathrm{~mm}$ thick, outline broadly subpyriform, sligthly wider than long $(w / L: 1.03)$, relatively thick $(t / L$ : 0.51 ), strongly ventri-biconvex, greatest convexity of ventral valve at the umbo, and near mid-length in the dorsal valve, cardinal angles obtuse $\left(\beta: 127^{\circ}\right)$, postero-lateral commissures straight, lateral and anterolateral commissures rounded, with a weakly notched margin and sulcate anterior commissure (Fig. 8d5); greatest width anterior to half length (wmax: 63\% L); hinge shorter than the greatest width ( $h w: 66 \%)$; shell multicostellate, ornamented with more than 70 fine, nearly straight subangular radial ridges, with similar interspaces that increase by bifurcation along three division levels, 10-11 primary costae slightly stronger than secondaries, 18 radial ribs per $5 \mathrm{~mm}$ at a distance of $7 \mathrm{~mm}$ from the beak (Figs 8d2, 8d3). Ornament formula very simple with few costellae in each sector, bundling from sector II to posterolateral sectors (X-XI):
Formula of sectors $M$ to $I V$ (ventral valve): $\mathrm{Ma}^{\mathrm{o}}, \mathrm{Mb}^{\circ}$ $1 \mathrm{a}^{-}, 1 \mathrm{~b} ; 2 \mathrm{a}^{-}, 2 \mathrm{~b}^{-}, 2 \mathrm{a}^{\mathrm{o}} ; 3 \mathrm{a}^{-}, 3 \mathrm{a}^{\mathrm{o}} ; 4 \mathrm{a}^{-}, 4 \mathrm{a}^{\circ} \ldots$

Growth lamellae numerous (more than ten), sometimes slightly imbricate, accumulated chiefly near the shell margin. Ventral valve hemipyramidal (Fig. 8d1), subpyriform (Fig. 8d3), four times deeper than dorsal valve, umbo strongly prolonged behind the hinge-line, beak straight to slightly inclined, apical angle acute $(\alpha$ : $88^{\circ}$ ), median fold weak, low, large, slightly accentuated axially by the primary costa $\mathrm{M}$ (Fig. $8 \mathrm{~d} 3$ ); the median fold includes ca. 19 radial ribs at the anterior margin; sides flattened; interarea well-developed, ca. $5.49 \mathrm{~mm}$ wide and $8.96 \mathrm{~mm}$ long, apsacline although not steeply, weakly concave and transversely grooved with sharp posterior margins, delthyrium triangular, open, ca. one-third as large as the interarea width, encompassing an angle of $47^{\circ}$, and a developed apical ventral callist (Fig. 8d2). Dorsal valve ca. $10 \mathrm{~mm}$ long, suboval, about four times lower than ventral valve, evenly convex both longitudinally and transversally excepting for the presence of a median sulcus wich is narrow, acute, widening and deepening anteriorly, and reaching the anterior margin where it occupies ca. 56 per cent the shell width (Fig. 8d5); beak minute, interarea moderately well-developed, ca. four times shorter than ventral interarea, anacline, flattened, transversally grooved,

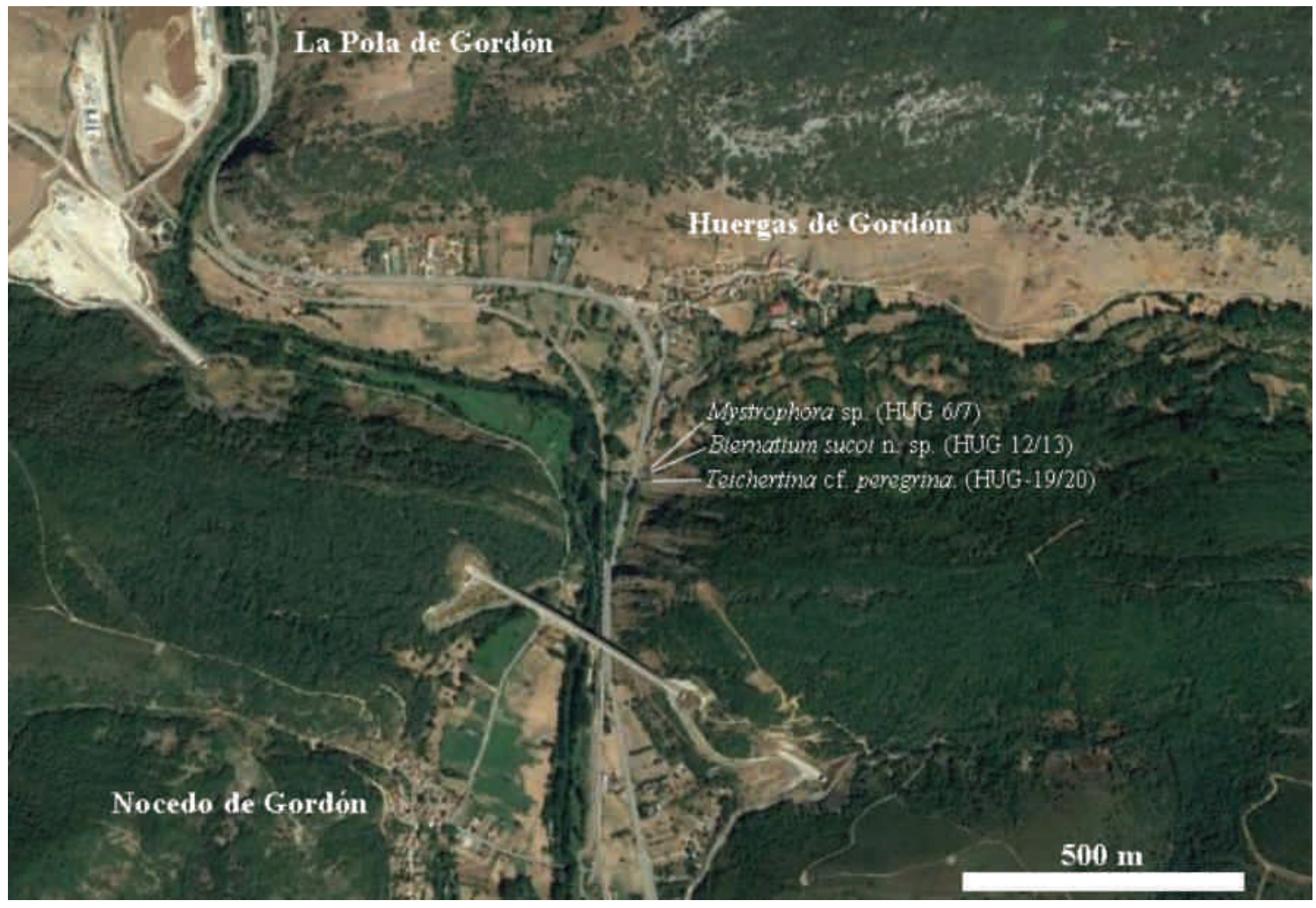

Figure 9. Section of the Portilla Fm., south Huergas de Gordón (La Pola de Gordón, province of León) where Mystrophora sp., Biernatium sucoi nov. sp., and Teichertina cf. peregrina Havlíček, 1977 have been found. Aerial photo (oriented north): SIGPAC (Castilla and León). 
sharply defined, nothothyrium open, large, partially filled by the cardinal process. Interior of both valves unknown, but the dorsal umbo and dorsal sulcus of the available specimen record clear traces both of a cruralium and a relatively long median septum.

Discussion. The general morphology of the specimen at hand is quite close to the Mystrophora, especially the shell outline, hemipyramidal ventral valve, sulcate character, and fine ornamentation. The lack of additional material prevents an undoubted and definite classification. The type species of Mystrophora, M. areola (Quenstedt, 1871 ) is close to the Spanish form, but it is smaller, coarser ornamented, more transverse, with stronger ventral valve fold and dorsal sulcus, and with more marked anterior notching.

\section{Genus Biernatium Havlíček, 1975}

Diagnosis. Transversely semioval, ventri-biconvex, coarsely costellate shell, weak ventral valve fold not always readily discernible, ventral interarea fairly long, apsacline to catacline, delthyrium bounded by narrow deltidial plates that meet apically to form a small apical plate; dorsal valve sulcate; interarea anacline to catacline, nothothyrium open, bounded laterally by narrow chilidial plates. Semi-fascicostellate to fascicostellate, isorthoid pattern of radial ornamentation with primary costae much stronger than secondaries. Ventral interior with short dental plates, ventral muscle field confined to delthyrial cavity, resting on a thickened muscle platform, muscle scars indistinct. Dorsal interior with a small, bilobed cardinal process; long, blade-like brachiophores; dental sockets with no fulcral plates; antero-ventrally directed cruralium, supporting the muscle field, narrowing distally to disappear anterior to mid length; crural plates attached to the sides of a very high, narrow median septum with maximum height at about mid-length where it touches the floor of the ventral valve; median septum rapidly losing height afterwards to disappear near the anterior margin.

Discussion. Biernatium is a poorly known genus embodying a handful of usually poorly represented species (see above). According to Havliček (1974), Kayserella lepida Biernat, 1959 (non Orthis lepida Schnur, 1853), Kayserella emanuelensis Veevers, 1959, and with a question mark Kayserella cf. lepida Anderson, Boucot \& Johnson, 1969 (non Orthis lepida Schnur, 1853) would be reassigned to Biernatium due to their rather long cruralium which is unlike the minute septalium of Kayserella Hall \& Clarke, 1892. By the same token, Kayserella costatula Lenz, 1977 is included here in Biernatium due to its quite long cruralium and rounded outline. However, it is very questionable whether Anderson et al.'s (1969) Kayserella

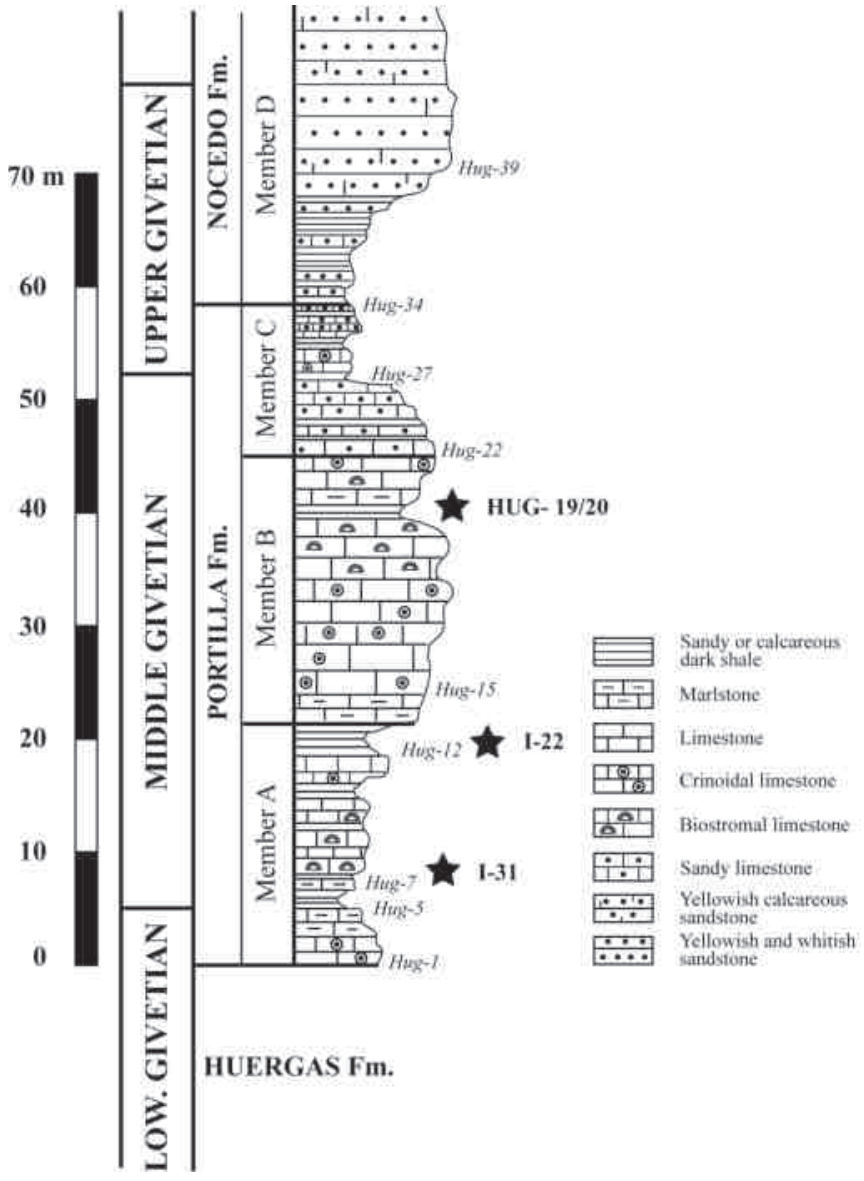

Figure 10. Stratigraphic column of the Portilla Fm., south Huergas de Gordón (La Pola de Gordón, province of León) (Fig. 9), with the setting of Mystrophora sp. (black star, locality I-31), Biernatium sucoi nov. sp. (black star, locality I-22), and Teichertina cf. peregrina (black star, level HUG-19/20).

cf. lepida can be referred to Biernatium. In fact, the figures provided by the authors seem to correspond to different forms. A fragmentary dorsal valve in figure 1 of plate 2 is not a Kayserella, differing in a larger cruralium; it could be assigned either to Biernatium, after the lack of fulcral plates, or to Mystrophora, because their relatively short cruralium. On the other hand, figures 2-3 in plate 2 represent a small complete shell that departs absolutely from Kayserella lepida and Biernatium fallax (Gürich, 1896). In fact, it is a semicircular shell, with hinge-line only slightly shorter than the greatest shell width, with a catacline ventral interarea, ornamentation unbranched or nearly so, with numerous strong, simple costae, with the dorsal sulcus showing a median, strong rib. All these characters seem much closer to Skenidium or Skenidioides than to the dalmanellaceans. New observations concerning the shell structure of this specimen could contribute in clearing up this question. Anyway the discussed reference is so much uncertain that cannot be considered for the moment. 
Mystrophora Kayser, 1871 differs from Biernatium in its typical pentagonal outline, higher ventral interarea, much finer ornamentation, in having fulcral plates, and a more elaborate cruralium. The Eifelian Kayserella Hall \& Clarke, 1892 is another superficially close taxon that clearly departs from Biernatium in the structure of the cruralium being much smaller, confined to the nothothyrial chamber, and bounded antero-laterally by the brachiophore supporting plates. The Pragian Planicardinia Savage, 1968 differs in the occurrence of a cruralium perpendicular to valve floor, a plano-convex lateral profile, a ventral interarea anacline, a hypercline dorsal interarea, and strong dental plates.

Biernatium sucoi nov. sp.

(Figs 1-3, 9-14, 15a1-15k2, 19a)

Derivatio nominis. Dedicated to Professor D. Luis Carlos Sánchez de Posada, University of Oviedo (Spain), familiarly known to his friends and relatives as "Suco", as proof of deep friendship.

Material. Two hundred and sixty seven variably preserved specimens, but in general well enough, mostly complete shells, coming from the stratum and locus typicus, and other eight from different Asturo-Leonian localities. Holotype DPO 47845 (Fig. 15 a1-a5) and eighteen paratypes, DPO 47839, 47841, 47844, 47865, 47876, 47881, 47883-47884, 47898, 47907, 47910, 47914, 47928, 47933, 47935, 47938-47939, 47946 (Fig. 15), ten topotypes DPO 47941-47945 y 47947-47951, prepared for serial sections, eighty four well preserved topotypes DPO 47840, 47842-47843, 47846-47864, 47866-47875, 47877 47880, 47882, 47884-47897, 47899-47906, 47908-47909, 47911-47913, 47915-47927, 47929-47930, 47932, 47934, 47936-47937, 47940 (Fig. 15), one hundred and fifty two poor to very poorly preserved topotypes, DPO 47954

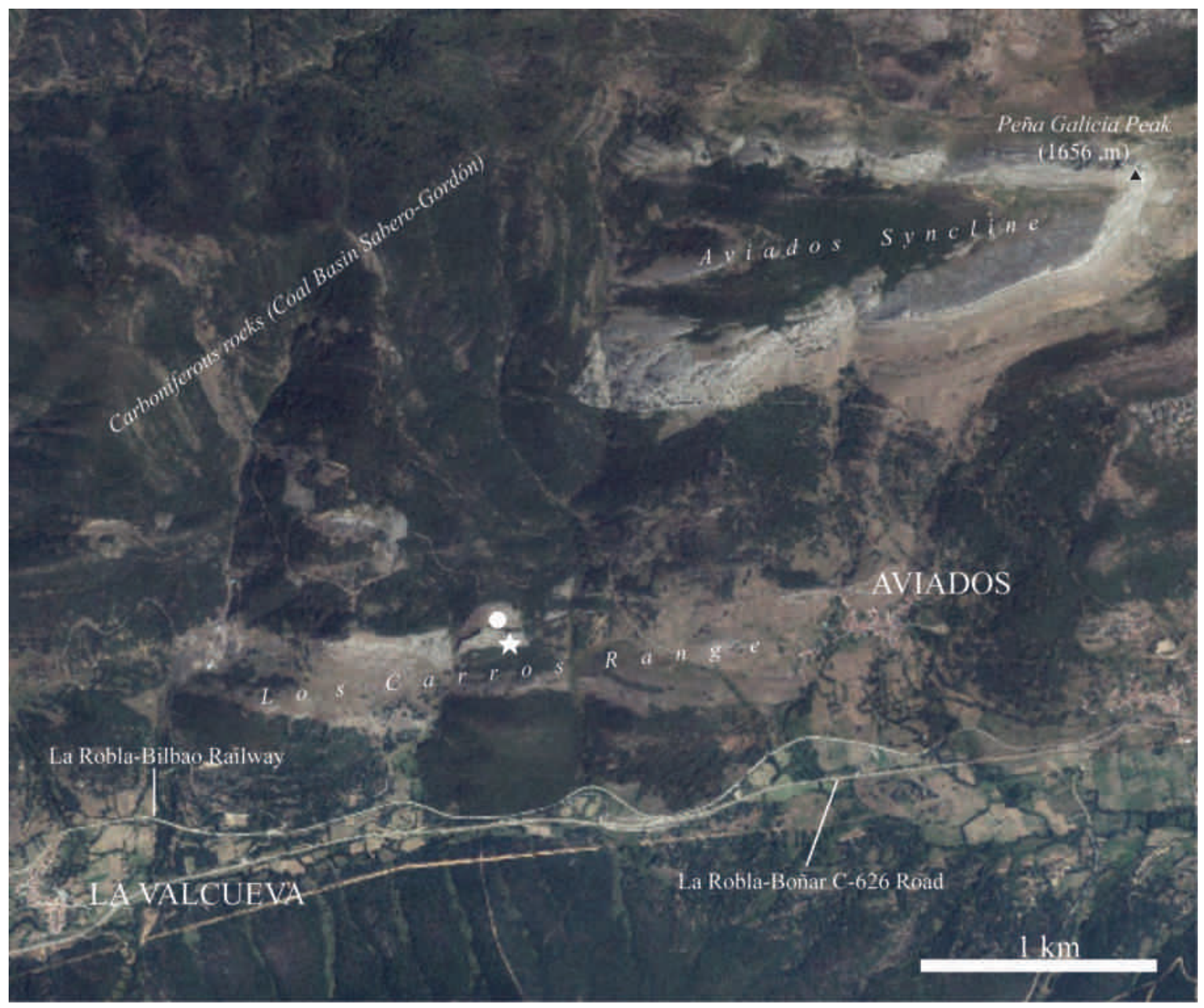

Figure 11. White star: Type locality Z-33 of Biernatium sucoi nov. sp., coordinates SIGPAC (Castilla and León) 4251'31.39'N, 5²7'45.38'W, Los Carros Range, west Aviados (Boñar, province of León). White circle: Locality K-79 (Z-35) of Teichertina cf. fitzroyensis (Veevers, 1959), 4251'32.84'N, 5²7'48.59'W. Aerial photo (oriented north) and coordinates: SIGPAC (Castilla and León). 
48105, from the stratum and locus typicus. Five poorly preserved specimens, DPO 48206-48210 from the section south of Huergas de Gordón (León province), Portilla Fm., top of A Member, HUG-12/13 level, locality I-22, middle Givetian (Figs 9-10). One specimen DPO 48193 from the southern slope of Las Traviesas Mountains, north of Cermoño (Salas, Asturias province) (Fig. 7), Candás Fm., lower part, beds with Davidsonia verneuili, lower to middle Givetian. Two very well preserved specimens DPO 48211-48212, from the shore section, west of La Punta de la Vaca, Luanco, Asturias, localities K-40 and K-41, respectively, lower part of the Candás Fm., ca. 30-40 m above the base of formation, middle Givetian.

Locus and stratum typicum. Las Pozas de Santa Eugenia, West Aviados (La Vecilla, León province), fine layers of marly limestones interbedded between coralligenous limestones with abundant Davisonia verneuili, middle part of the Portilla Fm. above biostromal limestones with abundant $D$. verneuili, locality Z-33 (coordinates SIGPAC 4251'31.39”N, 5²7’45.38”W) (Figs 1, 11), middle Givetian.

Diagnosis. Ventral valve provided with a weak, low and large median fold, with the axial line accentuated by a median costa $\mathrm{M}$; relatively simple, weakly semifascicostellate, isorthoid radial ornamentation, 7-8 pairs of primary costae, sectors I and II (dorsal valve) usually with internal first-order secondary costellae $1 \mathrm{a}^{-}$ and $1 b^{-}$, sector III and following sectors more or less fascicostellate with internal and external first-order secondaries, $3 \mathrm{a}, 3 \mathrm{a}^{\circ}, 4 \mathrm{a}^{-}, 4 \mathrm{a}^{\mathrm{o}}$, and so on; the more developed radial ribs and the corresponding interspaces appear when greatly magnified as superimposed on a system of very fine sub-radial capillae chiefly visible anteriorly; brachiophores tapering ventrally, very high, reaching the floor of ventral valve, cruralium composed of crural plates flaring ventrolaterally, attached to sides of median septum, disappearing anteriorly at a point near mid-length.

Description. Shell small in size (1.5 to $7.5 \mathrm{~mm}$ long in available material), outline subcircular to transversely oval (average $w / L: 1.16$, from 99 measurements) with obtuse, rounded cardinal margins (average of cardinal angle, $\beta: 138^{\circ}$, from 71 measurements), ventri-biconvex and thick (average $t / L: 0.59$, from 99 measurements), with maximum thickness and convexity of both valves greatest posteriorly, anterior and lateral borders more or less flattened, greatest shell width at mid-length (average wmax: 49\%L, from 80 measurements), hingeline shorter than the greatest width (average $h w: 75 \%$, from 71 measurements) (Table 2), well-developed ventral valve umbo, anterior commissure broadly sulcate, lateral commissures sigmoidal. Ornamentation isorthoid with radial ribs subangular, wider than interspaces, central
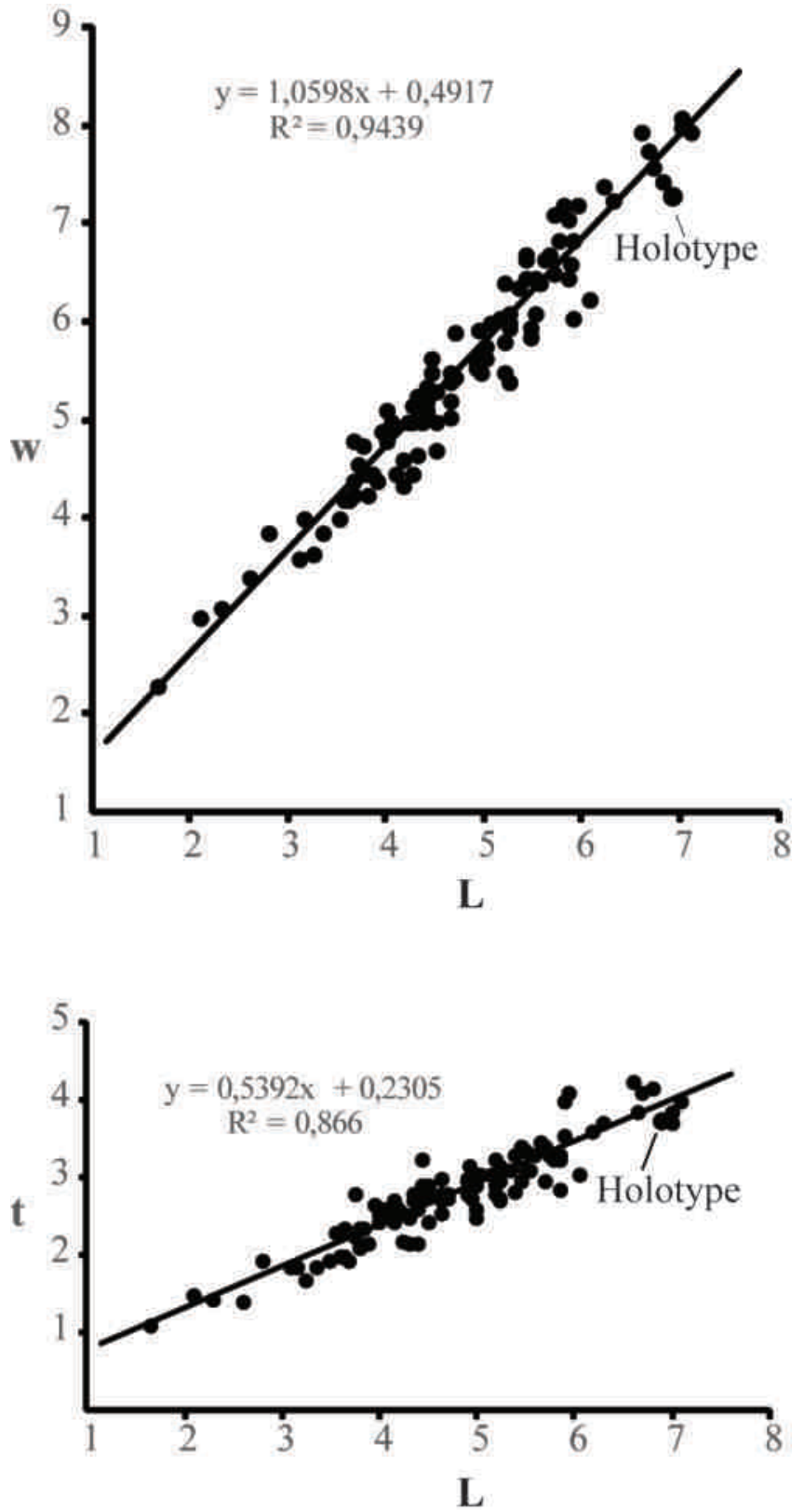

Figure 12. Biernatium sucoi nov. sp. Scatter diagrams showing length/width (L/w) and Length/thickness $(\mathrm{L} / \mathrm{t})$ ratios.

ribs straight, lateral ribs bending postero-laterally, but not intersecting the cardinal area margins; 7-8 paired primary costae much stronger than secondaries (Figs 15a1, 15g1, $15 \mathrm{~h} 2,15 \mathrm{k} 2$ ); postero-lateral ribs are so undifferentiated as to make it difficult to segregate them into primary and secondary elements (i.e. Fig. 15a2); secondaries increase by dichotomy along 2-3 division levels; the number of ribs at the anterior margin varies between 14-16 in younger shells (ca. $1.7 \mathrm{~mm}$ long) to 54-64 in mature specimens (ca. $7 \mathrm{~mm}$ long), with 20 radial elements per $5 \mathrm{~mm}$ at a distance of about $3 \mathrm{~mm}$ from the beak. Ventral valve with the isorthoid rib system in which a strong primary costa $\mathrm{M}$ 


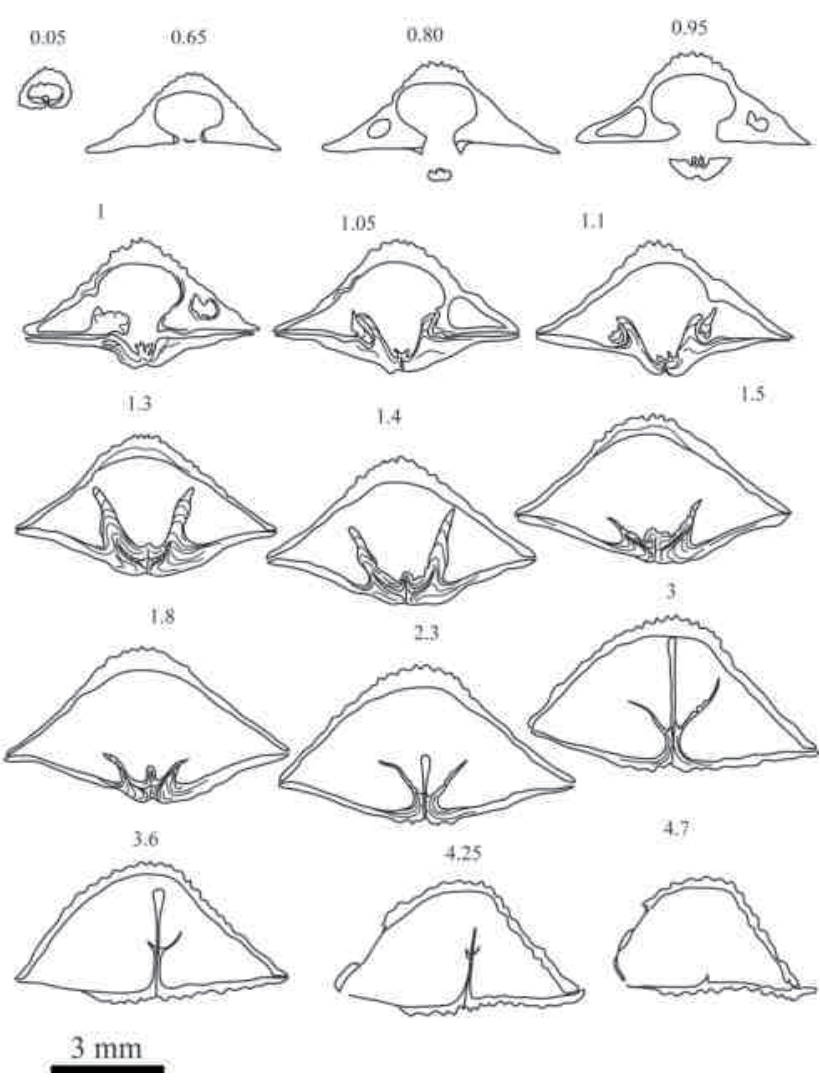

Figure 13. Biernatium sucoi nov. sp. DPO 47941, serial sections. Numbers indicate distances (in $\mathrm{mm}$ ) from the ventral apex.

gives way soon on each side to one first-order secondary costella $\mathrm{Ma}^{\circ}$ (Fig. 15k2), and sometimes in later growth stages to another pair of $\mathrm{Mb}^{\circ}$ that can bifurcate further in more mature specimens, giving way to second-order secondaries $\mathrm{Ma}^{\circ} 1^{\circ}, \mathrm{Mb}^{\circ} 1^{\circ}$; dorsal valve with paired submedian primary costae that usually bifurcate anteriorly one or two times in $1 \mathrm{a}^{-}$and $1 \mathrm{~b}^{-}$, and further split off in second-order secondaries $1 \mathrm{a}^{-1} 1^{-}$, and $1 \mathrm{~b}^{-1} 1^{-}$(Figs 15a2, 15b2, $15 \mathrm{e} 2,15 \mathrm{~h} 3$ ); sector II develops also first-order secondaries $2 \mathrm{a}^{-}$and $2 \mathrm{~b}^{-}$which can bifurcate further into second-order secondaries $2 \mathrm{a}^{-} 1^{-}$and $2 \mathrm{~b}^{-} \mathrm{1}^{-}$; sector III and next sectors are fascicostellate with first-order secondaries originated on both inner and outer sides of primaries, $3 \mathrm{a}^{-}, 3 \mathrm{a}^{\circ}, 4 \mathrm{a}^{-}, 4 \mathrm{a}^{\circ}$, and so on; the bundles can branch further in old shells by the splitting off of second- and third-order secondaries, internal in dorsal valves and external in ventral valves; in the best preserved shells an extremely thin median dorsal capilla runs along the sulcus bottom. The more general early ephebic costellae formula (dorsal valve) is as shown below:

Sectors $I-I V: 1 \mathrm{a}^{-1} 1^{-}, 1 \mathrm{~b}^{-} ; 2 \mathrm{a}^{-1} 1^{-}, 2 \mathrm{~b}^{-} ; 3 \mathrm{a}^{-1} 1^{-}, 3 \mathrm{~b}^{-}, 3 \mathrm{a}^{\mathrm{o}} ; 4 \mathrm{a}^{-}$, $4 \mathrm{a}^{\mathrm{o}} \ldots$

Non-symmetrical ornament is quite frequent, i.e. equivalent left and right secondaries or costellae bundles arise either in different growth stages or along different primary costae, and likewise some secondaries can develop only on one side of the shell. Both the radial ribs and their intervening interspaces appear superimposed on a system of very fine sub-radial capillae, visible chiefly near the shell margins. Growth lines few, usually only one which occurs very close to or matching the beginning of the ephebic growth stage; fine concentric growth filae numerous, visible at high magnifications on well preserved specimens. Ventral valve longer than dorsal valve, median fold low, large, not always readily discernible, embracing sectors $\mathrm{M}$, I, and II, ventral valve weakly carinate along the primary M (Figs 15a4, $15 \mathrm{~b} 4,15 \mathrm{~g} 4,15 \mathrm{~h} 5)$, greatest convexity in medial transversal section, sides flattened, greatest convexity in longitudinal section at the umbonal region; interarea, high, concave, strongly apsacline (Fig. 15f2), transversal- and subradially grooved, beak straight to suberect with obtuse apical angle (average $\alpha: 111^{\circ}$, from 71 measurements) (Table 2), delthyrium open, one-quarter to one-seventh as wide as hinge, with fine deltidial plates converging posteriorly to form a small, convex apical plate (Fig. 15f3). Dorsal valve shorter than ventral valve, strongly sulcate, sulcus beginning near the apex of valve where it is narrow and

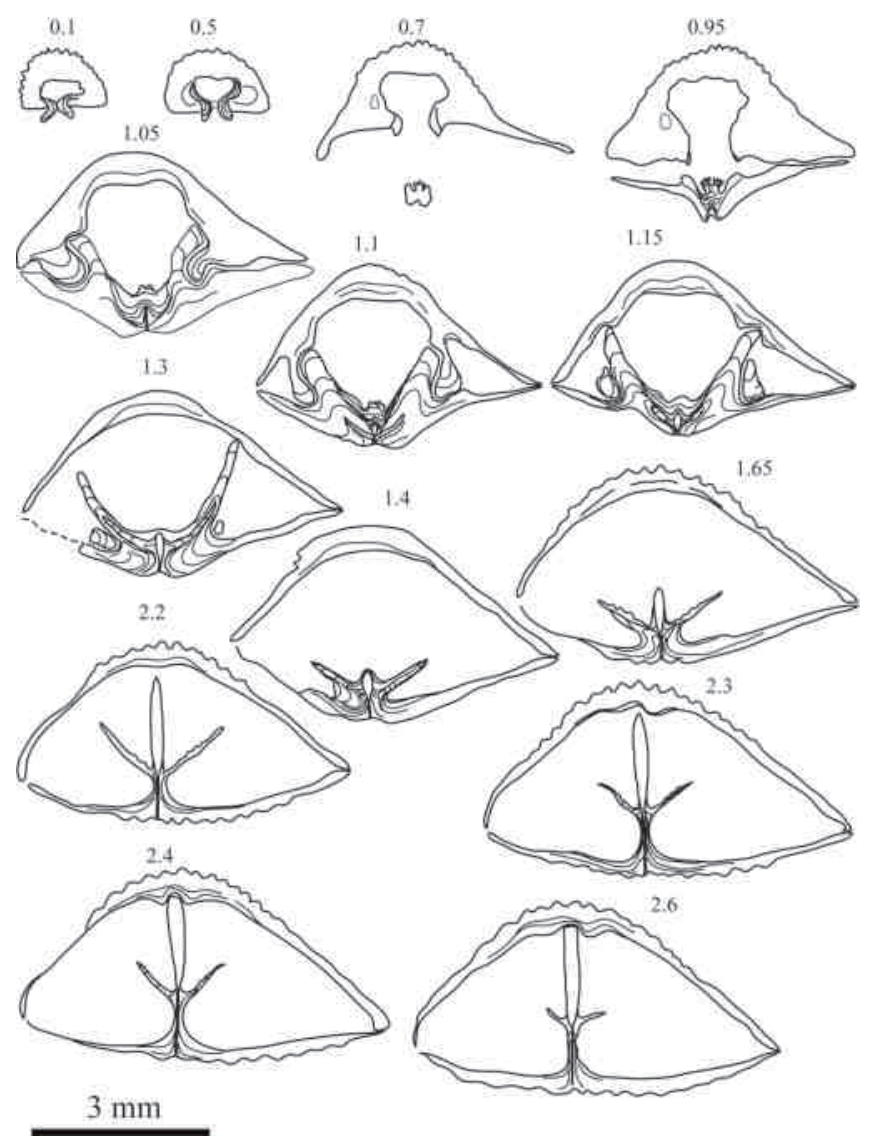

Figure 14. Biernatium sucoi n.sp. DPO 47947, serial sections. Numbers indicate distances (in $\mathrm{mm}$ ) from the ventral apex. 
Table 2. Biernatium sucoi nov. sp. Measurements of some selected specimens. Abbreviations as in Table 1.

\begin{tabular}{|c|c|c|c|c|c|c|c|c|c|}
\hline DPO & $\mathrm{L}$ & $\mathrm{w}$ & $\mathrm{t}$ & $\mathrm{w} / \mathrm{L}$ & $\mathrm{t} / \mathrm{L}$ & hw & $\alpha$ & $\beta$ & wmax \\
\hline Paratype 47839 & 7.1 & 7.95 & 4 & 1.12 & 0.56 & 71 & 110 & 146 & 49 \\
\hline Topotype 47840 & 7 & 8.1 & 3.7 & 1.16 & 0.53 & 80 & 124 & 130 & 47 \\
\hline Paratype 47841 & 7.25 & 8.15 & 4.04 & 1.12 & 0.56 & 72 & 112 & 153 & 49 \\
\hline Topotype 47842 & 7 & 8 & 3.85 & 1.14 & 0.55 & 74 & 104 & 141 & 51 \\
\hline Paratype 47844 & 6.6 & 7.95 & 4.25 & 1.2 & 0.64 & 72 & 101 & 150 & 50 \\
\hline Holotype 47845 & 6.9 & 7.3 & 3.75 & 1.06 & 0.54 & 76 & 118 & 147 & 50 \\
\hline Topotype 47846 & 6.2 & 7.4 & 3.75 & 1.19 & 0.6 & 77 & 111 & 146 & 52 \\
\hline Topotype 47849 & 6 & 6.8 & 3.05 & 1.13 & 0,51 & 78 & 103 & 138 & 46 \\
\hline Topotype 47851 & 5.9 & 6.85 & 3.55 & 1.16 & 0.6 & 88 & 98 & 125 & 53 \\
\hline Topotype 47853 & 5.85 & 6.6 & 3.25 & 1.13 & 0.56 & 81 & 102 & 128 & 48 \\
\hline Topotype 47854 & 5.85 & 7.05 & 2.85 & 1.2 & 0.49 & 71 & 109 & 133 & 49 \\
\hline Topotype 47855 & 5.85 & 6.45 & 3.3 & 1.1 & 0.56 & 81 & 105 & 122 & 47 \\
\hline Topotype 47857 & 5.75 & 6.85 & 3.3 & 1.19 & 0.57 & 83 & 110 & 128 & 57 \\
\hline Topotype 47861 & 5.55 & 6.4 & 3.1 & 1.15 & 0.56 & 74 & 112 & 138 & 48 \\
\hline Topotype 47863 & 5.45 & 5.85 & 2.95 & 1.007 & 0.54 & 75 & 113 & 144 & 49 \\
\hline Paratype 47865 & 5.2 & 6.4 & 3.25 & 1.23 & 0.62 & 75 & 107 & 146 & 45 \\
\hline Topotype 47866 & 5.5 & 6.1 & 3.35 & 1.11 & 0.61 & 75 & 104 & 135 & 49 \\
\hline Topotype 47869 & 5.35 & 6.35 & 3.1 & 1.19 & 0.58 & 77 & 114 & 125 & 47 \\
\hline Paratype 47876 & 6.65 & 7.75 & 3.85 & 1.16 & 0.58 & 70 & 112 & 141 & 40 \\
\hline Topotype 47877 & 5.2 & 5.8 & 2.8 & 1.11 & 0.59 & 78 & 113 & 144 & 51 \\
\hline Topotype 47879 & 5.05 & 6 & 3.05 & 1.19 & 0.6 & 77 & 109 & 137 & 48 \\
\hline Topotype 47880 & 5 & 5.75 & 2.9 & 1.15 & 0.58 & 78 & 110 & 144 & 48 \\
\hline Paratype 47881 & 4.9 & 5.55 & 2.8 & 1.13 & 0,57 & 76 & 104 & 148 & 49 \\
\hline Topotype 47882 & 5 & 5.65 & 2.5 & 1.13 & 0.5 & 74 & 105 & 130 & 51 \\
\hline Paratype 47883 & 4.9 & 5.6 & 3 & 1.14 & 0.61 & 76 & 111 & 148 & 52 \\
\hline Paratype 47884 & 4.4 & 5.35 & 2.7 & 1.21 & 0.61 & 69 & 113 & 151 & 50 \\
\hline Topotype 47888 & 4.7 & 5.45 & 2.75 & 1.16 & 0.58 & 78 & 110 & 143 & 50 \\
\hline Topotype 47889 & 4.65 & 5.4 & 2.75 & 1.16 & 0.59 & 71 & 109 & 144 & 58 \\
\hline Topotype 47891 & 4.65 & 5.05 & 2.8 & 1.09 & 0.6 & 78 & 115 & 130 & 43 \\
\hline Topotype 47896 & 4.65 & 5.2 & 2.7 & 1.12 & 0.58 & 78 & 120 & 142 & 49 \\
\hline Topotype 47897 & 4.65 & 5.2 & 2.55 & 1.12 & 0.55 & 77 & 110 & 144 & 49 \\
\hline Paratype 47898 & 4.25 & 5.15 & 2.2 & 1.21 & 0.52 & 76 & 114 & 148 & 54 \\
\hline Topotype 47901 & 4.4 & 5.25 & 2.6 & 1.19 & 0.59 & 75 & 115 & 144 & 46 \\
\hline Topotype 47902 & 4.4 & 5.1 & 2.6 & 1.16 & 0.59 & 76 & 114 & 142 & 54 \\
\hline Topotype 47903 & 4.4 & 5.2 & 2.15 & 1.19 & 0.49 & 56 & 113 & 148 & 64 \\
\hline Topotype 47906 & 4.3 & 4.65 & 2.15 & 1.08 & 0.5 & 75 & 98 & 130 & 48 \\
\hline Paratype 47907 & 3.75 & 4.75 & 2.8 & 1.27 & 0.75 & 79 & 111 & 138 & 48 \\
\hline Topotype 47909 & 4.25 & 4.45 & 2.55 & 1.05 & 0.6 & 68 & 104 & 144 & 44 \\
\hline Paratype 47910 & 4.35 & 5.15 & 2.8 & 1.18 & 0.64 & 78 & 109 & 142 & 43 \\
\hline Topotype 47911 & 4.2 & 5 & 2.6 & 1.19 & 0.62 & 64 & 118 & 148 & 52 \\
\hline Paratype 47914 & 4.4 & 5.05 & 2.65 & 1.15 & 0.6 & 76 & 104 & 147 & 44 \\
\hline Topotype 47918 & 3.95 & 4.9 & 2.65 & 1.24 & 0.67 & 77 & 144 & 126 & 51 \\
\hline Topotype 47927 & 3.65 & 4.25 & 2 & 1.16 & 0.55 & 66 & 116 & 134 & 51 \\
\hline Paratype 47928 & 4 & 4.9 & 2.55 & 1.22 & 0.64 & 72 & 113 & 139 & 50 \\
\hline Topotype 47930 & 3.5 & 4 & 1.95 & 1.14 & 0.56 & 76 & 113 & 131 & 45 \\
\hline Paratype 47931 & 2.8 & 3.85 & 1.95 & 1.37 & 0.7 & 73 & 118 & 140 & 38 \\
\hline Topotype 47932 & 3.35 & 3.85 & 1.85 & 1.15 & 0.55 & 72 & 110 & 133 & 54 \\
\hline Paratype 47933 & 3.25 & 3.65 & 1.7 & 1.12 & 0.52 & 70 & 113 & 139 & 50 \\
\hline Topotype 47934 & 3.15 & 4 & 1.85 & 1.27 & 0.59 & 71 & 120 & 141 & 51 \\
\hline Paratype 47935 & 2.3 & 3.1 & 1.45 & 1.35 & 0.63 & 69 & 112 & 145 & 50 \\
\hline Topotype 47936 & 3.1 & 3.6 & 1.85 & 1.16 & 0.6 & 70 & 108 & 138 & 51 \\
\hline Topotype 47940 & 1.65 & 2.3 & 1.1 & 1.39 & 0.67 & 73 & 125 & 137 & 55 \\
\hline Topotype 47946 & 2.1 & 3 & 1.5 & 1.43 & 0.71 & 70 & 113 & 139 & 50 \\
\hline
\end{tabular}


acute, deepening and widening anteriorly to take up more than half of the greatest width at the anterior commissure (Figs 15a5, 15e5, 15g3, 15f5); in longitudinal section maximum convexity umbonal, anterior margin nearly flat; in transversal view, sides flattened, even slightly concave; dorsal beak smaller than ventral beak, interarea welldeveloped, strongly anacline to catacline, even weakly hypercline (Fig. 15e3), one-third as long as the ventral interarea, slightly concave, grooved similarly to that of the ventral valve, nothothyrium open, bounded by fine chilidial plates.

Interior of ventral valve. Delthyrial cavity deep, blunt teeth supported by recessive dental plates, well-developed crural fossettes accommodating the brachiophore edges, small post-dental accessory plates to receive the outer socket ridges, muscle field confined to delthyrial cavity, on a thickened muscle platform, muscle scar indistinct; marginal crenulations strongly marked (Fig. 15ka1).

Interior of dorsal valve. Cardinal process low, short, bilobed, developed on a weak notothyrial platform, brachiophores plate-like, tapering ventrally, very high and reaching the bottom of ventral valve (Fig. 15j1), with relatively short bases diverging more than $90^{\circ}$; the brachiophore plates bound internally shallow, denticulate dental sockets; isolated dorsal valves DPO 47933 and DPO 47939 show the dental sockets as they were supported by fulcral plates (Figs 15i, 15j1), but this impression isn't confirmed by serial sections (Figs 13-14); cruralium long, resting proximally on the valve floor in the nothothyrial chamber and rising afterwards distally to a high termination at midlength, crural plates flaring ventro-laterally, attached to sides of median septum (Figs 15i, 15j1, 15j2); minute grooves on the crural plates floor (seen in serial sections, Figs 13-14) denote muscle attachment; dorsal septum narrow, medianly split off posteriorly, very high, touching the bottom of ventral valve at midlength, and even situated upon it (Fig. 13, section $4.7 \mathrm{~mm}, 14$, section $3 \mathrm{~mm}$ ), rapidly losing height anteriorly so as to distally almost reach the anterior margin; the septum consists of a fibrous inner layer in its basal half, which extends distally as a wedge-shaped plate of undifferentiated (in serial sections) microstructure (Fig. 19a); margin of valve strongly crenulated, with long, deep longitudinal furrows to accommodate sensitive setae (Figs 15j1, 15k1).

Ontogeny. The good preservation of available material allows for one to recognise fairly well the successive growth stages. Post-larval protegulal nodes are always visible on shell apices; they are convex, unornamented, transversely elliptical, 0.1-0.18 mm long. Brephic (or nepionic) stage is represented by the occurrence of a few obscure concentric growth lines around the protegulal node, $0.18-0.2 \mathrm{~mm}$ from beaks; neanic stage begins with the occurrence of 6-8 pairs of subangular, primary ribs radiating around the brephic shell; shortly at ca. $0.2-0.3$ $\mathrm{mm}$ from the beak the first dichotomous phase occurs, at which the isorthoid rib system is achieved, i.e. one secondary costella $\mathrm{Ma}^{\mathrm{o}}$ appear on each side of costa $\mathrm{M}$ in ventral valve, and secondary costellae $1 \mathrm{a}^{-}$splits off from costae 1 in the dorsal valve; the late neanic stage records the splitting off of several new first-order secondary costellae in both valves, external in the ventral valve, $1 \mathrm{a}^{\circ}$, $2 \mathrm{a}^{\mathrm{o}} \ldots$, and internal in the dorsal valve, $2 \mathrm{a}^{-}, 3 \mathrm{a}^{-} \ldots$ This phase extends variably to $\mathrm{L}$ ca. $3.5-4.5 \mathrm{~mm}$, and records a trend to fascicostellation in the occurrence of internal secondaries in the ventral valve and external in the dorsal valve near the anterior margin in isolated, incipient bundles; the neanic shell achieves at this phase a subcircular to subelliptical outline that is retained with further growth; moreover, the dorsal valve develops moreover an acute median sulcus that extends from the protegulum and widens and deepens distally towards the anterior margin; an extremely faint median ridge, visible in the best preserved specimens, extends along the bottom of the sulcus. The regular occurrence of a fascicostellate pattern developed laterally from sectors III of the shell represents the adult condition in the species, i.e. the ephebic stage; the bundles are at first relatively simple, trifurcating with internal and external first-order secondary costellae along the primary costae; however, further branching occur in advanced growth phases by the appearance of new costellae, usually external in the ventral valves and internal in the dorsal valves, either along the primaries or splitting off from preceding secondaries; the occurrence of capillae at the distal ends of costae and costellae is also an usual advanced ephebic feature. Asymmetries are quite frequent along the entire extent of growth and both the delayed occurrence of equivalent costellae on each side of shell, and the formation of bundles on sides of the shell along different primaries are rather usual characters.

Discussion. B. sucoi nov. sp. departs from Biernatium simplicior (Barrande, 1879), Pragian of Bohemia, in its greater size, stronger ventribiconvex lateral profile, quite differing, wider than long, subcircular to subelliptical outline, shorter hinge-line, and a less developed ventral interarea and more branched ornament pattern. Biernatium costatulum (Lenz, 1977) from the Pragian-Zlichovian of northwestern Canada is also a somewhat evolved species, close to the contemporary $B$. simplicior. It is smaller in size than $B$. sucoi nov. sp., with a wider hingeline, subtrapezoidal, stronger sulcate dorsal valve, more developed dental plates, thicker ventral muscle platform with margins slightly raised on the valve floor, with much more reduced branching ornament, and a longer cruralium. The Givetian Polish material assigned by Biernat (1959) to Kayserella lepida (Schnur, 1853) and reassigned by Havlíček (1977) and Halamski (2009) to Biernatium fallax (Gürich, 1896) differs greatly from the lower Givetian Skały beds collection sampled by Halamski (2009) in its 

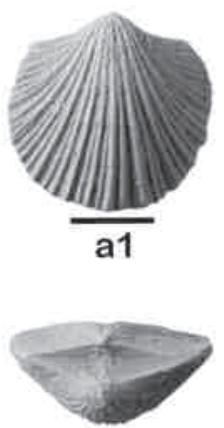

a4
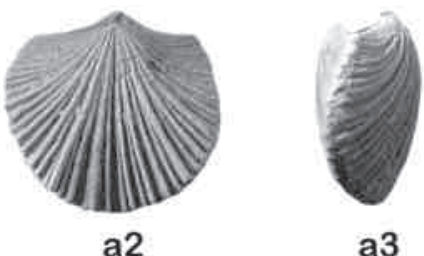

a3

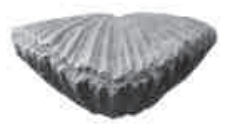

a5

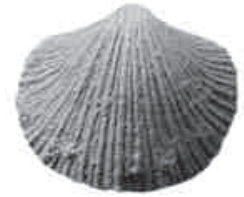

e1

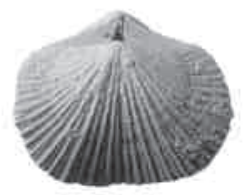

e2

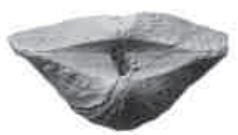

e4

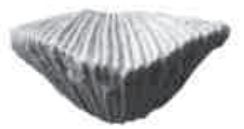

e5

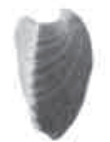

h4

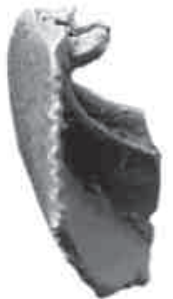

j2

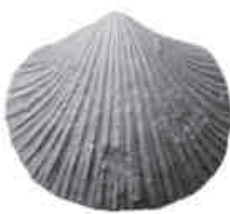

b1

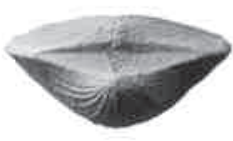

b4

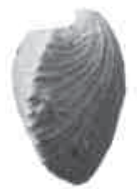

e3

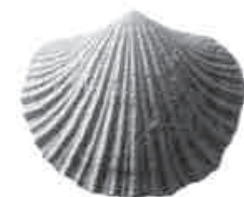

g1

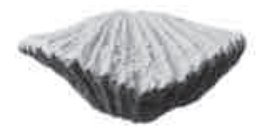

g3

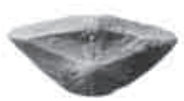

h5

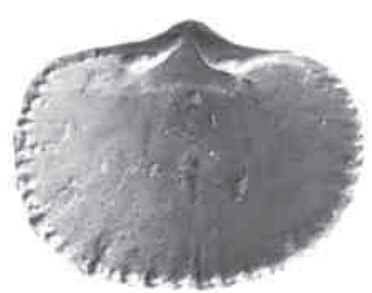

k1

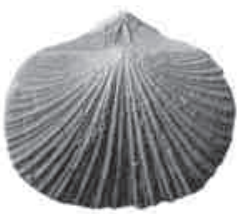

b2

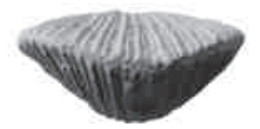

b5

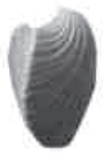

f2

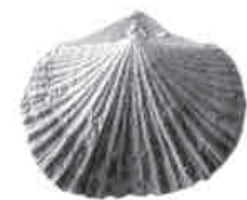

g2

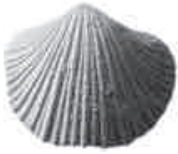

f1

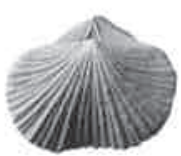

f3

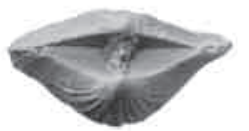

g4

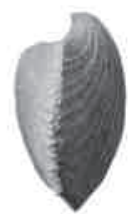

b3

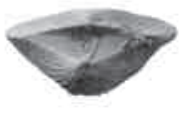

f4

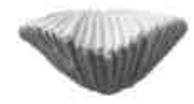

f5

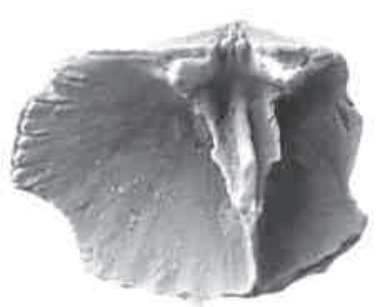

j1

Figure 15. Biernatium sucoi nov. sp. from the stratotype, Portilla Fm., middle Givetian. a1-a5) Holotype DPO 47845, ventral, dorsal, lateral, posterior, and anterior views. b1-b5) Paratype DPO 47839, ventral, dorsal, lateral, posterior, and anterior views. c1-c5) Paratype DPO 47935, ventral, dorsal, lateral, posterior, and anterior views of a young specimen. d1-d5) Paratype DPO 47931, ventral, dorsal, lateral, anterior, and posterior views of a young specimen. e1-e5) Paratype DPO 47844, ventral, dorsal, lateral, posterior, and anterior views. f1-f5) Paratype DPO 47865, ventral, lateral, dorsal, posterior, and anterior views. g1-g4) Paratype DPO 47876, ventral, dorsal, anterior, and posterior views. h1-h5) Paratype DPO 47907, anterior, ventral, dorsal, lateral, and posterior views. i) Paratype DPO 47933, fragmentary dorsal valve, internal view. j1j2) Paratype DPO 47939, fragmentary dorsal valve, ventral, and lateral views, showing the development and arrangement of cruralium. k1-k2) Paratype DPO 47938, ventral valve, internal and external views. Scale bar $=3 \mathrm{~mm}$. Small bar for Figs 15a-15b, 15e-15h; intermediate bar for Figs 15c-15d; large bar for Figs 15i-15k. 
semicircular outline, smaller size, longer hinge-line and flattened lateral profile. On the other hand, the material assigned by Havlíček (1977) to B. fallax from the Givetian of Moravia is too poorly preserved (two poorly-illustrated complete specimens and one isolated dorsal valve) to be unequivocally compared with the Polish collections. In this situation I prefer to compare our own species separately with each Polish collection assuming the Havlíček's specimens could be close enough to Halamski's specimens to consider both as belonging to the same species. Thus, Biernat's Kayserella lepida, would differ from Biernatium sucoi nov. sp. in the same respects as it differs from Halamski's B. fallax (see above). On the other hand, the Halamski's forms differ from our species in the weaker sulcation, longer hinge-line, hemipyramidal ventral valve, anacline dorsal interarea, more branched ornament, and shorter cruralium. Kayserella emanuelensis Veevers, 1959, from the upper Frasnian of Australia, is undoubtely a Biernatium species as proposed by Havlíček (1977, p. 207) due mainly to its cruralium being much longer than that of Kayserella; it differs from B. sucoi nov. sp. in its smaller size, more rounded outline, radial ornament with secondaries increasing both by branching and intercalation and a complete fascicostellate rib system, where the bundles are developed over the entire shell, and by a weaker sulcate dorsal valve and anterior commissure, and non-denticulate dental sockets. The Spanish lower Frasnian Biernatium sp. 2 is close to B. emanuelensis in size, lateral profile, and rounded outline, but differs in a less complete fascicostellation, with bundles developed chiefly from sectors II. The differences between B. sp. 2 and $B$. sucoi nov. sp. are reported below. As stated previously, the Mongolo-Okhotsk Biernatium asiaticum (Alekseeva in Alekseeva et al., 2006) must be removed from Biernatium because of its different transverse, subpentagonal outline and the morphology of cruralium, which is completely attached to the floor of the dorsal valve.

\section{Biernatium sp. 2}

(Figs 1-3, 16-17, 18a1-18c4, 19b)

Material. Eleven relatively well preserved complete shells from different localities in ESE Luanco (province of Asturias), Piñeres Fm. sensu García-Alcalde, 1985, FI 25, Palmatolepis transitans zone (García-López \& SanzLópez, 2002a), lower Frasnian. DPO 48194 from the Samarinchón Beach, W of Punta Boletos (Fig. 16), DPO 48195-48196, and 48198 (sectioned specimen, Fig. 17) from locality C-91 (Fig. 16), E Aramar Beach, DPO 48199, from locality C-90, Aramar Beach, DPO 48200, locality C-195, E Aramar Beach, SW Punta del Carmen, DPO 48201-48204, locality C-89, Aramar Beach, DPO 48205, locality C-88, El Truán Beach (Fig. 16).

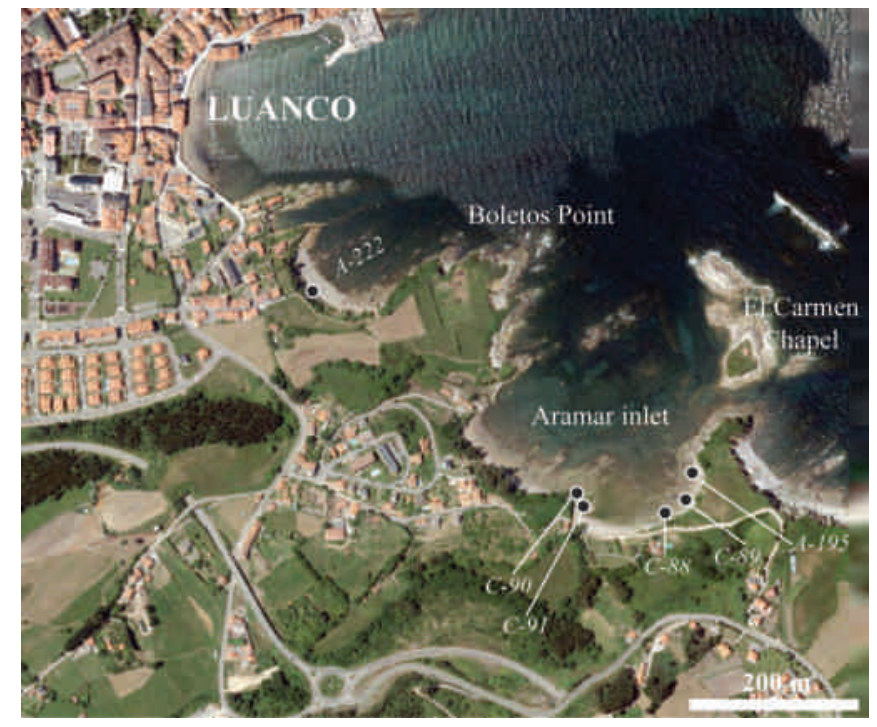

Figure 16. Black circles: localities where Biernatium sp. 2 has been found, in the section of the Piñeres Fm. (Upper Devonian, lower Frasnian) along the shoreline ESE Luanco (province of Asturias), Samarinchón, Aramar and El Truán beaches. Aerial photo (oriented North): SIGPAC Asturias.

Remarks. The general characters of Biernatium sp. 2 are quite close to $B$. sucoi nov. sp. Both taxa differ in size, being slightly smaller in the former species (Table 3 ), and in sulcation, being weaker in the latter one, but the more critical difference among them is in the radial ornament. Neanic $B$. sp. 2 ornament is very close to that of the adult $B$. sucoi nov. sp. but the ephebic form is more extensively fascicostellate. According the few available, well preserved specimens of $B$. sp. 2, the neanic formula (dorsal valve) should be as shown (compare with the $B$. sucoi $\mathrm{n}$. sp, above):

$1 a^{-} ; 2 a^{-} ; 3 a^{-} ; 4 a^{-}, 4 b^{-}, 4 a^{\circ}, 4 b^{\circ} \ldots$ as long as the ephebic formula (dorsal valve) would be: $1 \mathrm{a}^{-} ; 2 \mathrm{a}^{-}, 2 \mathrm{~b}^{-}, 2 \mathrm{a}^{\circ}$;

$3 \mathrm{a}^{-1}, 3 \mathrm{~b}^{-}, 3 \mathrm{a}^{\circ} ; 4 \mathrm{a}^{-}, 4 \mathrm{~b}^{-}, 4 \mathrm{a}^{\circ} \ldots$

Table 3. Biernatium sp. 2. Measurements of some selected specimens. Abbreviations as in Table 1.

\begin{tabular}{rrrccccccc} 
DPO & \multicolumn{1}{c}{$\mathrm{L}$} & \multicolumn{1}{c}{$\mathrm{w}$} & $\mathrm{t}$ & $\mathrm{w} / \mathrm{L}$ & $\mathrm{t} / \mathrm{L}$ & $\mathrm{hw}$ & $\alpha$ & $\beta$ & wmax \\
\hline 48195 & 5.71 & 7.18 & 3.25 & 1.25 & 0.45 & 76 & 113 & 144 & 52 \\
48196 & 4.16 & 5.13 & 2.25 & 1.23 & 0.54 & 65 & 114 & 143 & 46 \\
48199 & 5.26 & 6.2 & 2.81 & 1.18 & 0.53 & 67 & 127 & 150 & 48 \\
48200 & 6.5 & 7.75 & 3.91 & 1.19 & 0.60 & 73 & 106 & 136 & 58 \\
48205 & 5.88 & 6.16 & 3.23 & 1.05 & 0.55 & 69 & 107 & 140 & 55
\end{tabular}

During the course of the developmental history of Biernatium the ornament evolved from very simple, nearly unbranched to abundantly branched, largely fascicostellate patterns. The older species, B. simplicior (Barrande, 


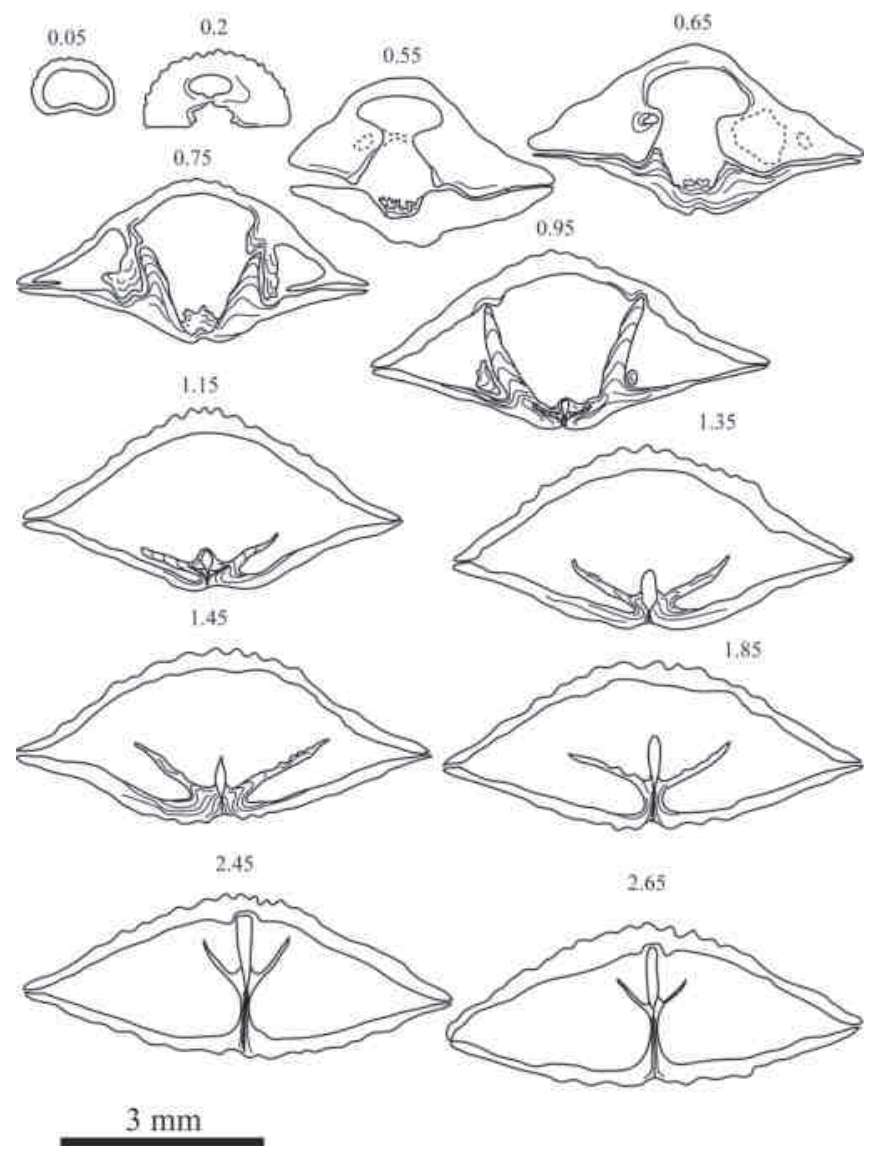

Figure 17. Biernatium sp. 2. DPO 48198, serial sections. Numbers indicate distances (in $\mathrm{mm}$ ) from the ventral apex.

1879), Pragian of Bohemia and B. costatulum (Lenz, 1977), Pragian-Zlichovian of northwestern Canada, are subfascicostellate forms, that aside from the isorthoid pattern develop only weak trends toward trifurcation in sectors III and IV (dorsal valve), as long as the other sectors remained unbranched or gave rise at the most to one internal first-order secondary costella on each primary costa. This pattern is retained in the known Middle Devonian species, B. fallax (Gürich, 1896) and B. sucoi nov. sp., and allegedly in other Biernatium forms corresponding to a long time span (upper Emsian to upper Eifelian) without Biernatium records. Anyway, the Middle Devonian Biernatium forms achieved more complete semifascicostellate patterns with bundles embracing a growing number of lateral sectors of the shell from that of sector III, and the usual occurrence of second-order secondaries. The known Upper Devonian forms represent the terminal step in this evolutionary trend: trifurcation extended there to median sectors of shell, I and/or II, in the lower Frasnian Spanish B. sp. 2, and to both I and II in the middle-upper Frasnian Australian B. emanuelensis (Veevers, 1959), in such a way that the bundles covered the whole shell.
The origin itself of Biernatium is uncertain. The more ancient Mystrophora, M. garraensis (Lenz \& Johnson, 1985), from the upper Lochkovian to lowermost Pragian Garra Fm., southeastern Australia, and M. arctica (Lenz, 1977), from the Zlichovian (lower Emsian) of the Road River Fm., Yukon, Canada, are very close to Biernatium simplicior (Barrande, 1879). Moreover, both Mystrophora species are small, even minute, transverse, strongly ventri-biconvex, with a subtrapezoidal outline, a hingeline slightly less than the greatest shell width, and a hemipyramidal ventral valve; the radial ornamentation is very simple, with primaries stronger than secondaries and alternating with them; bundles are either lacking or weakly developed in isolated sectors of the shell near the

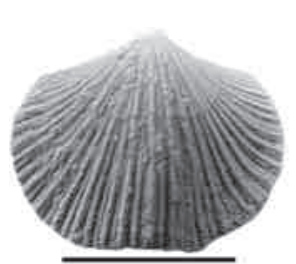

a1

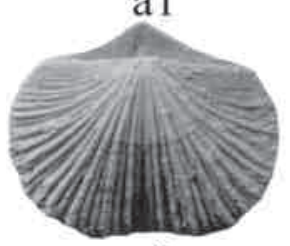

a2

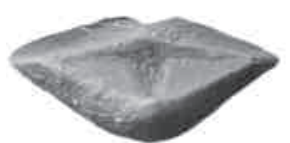

a3

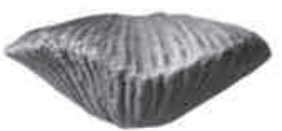

a4

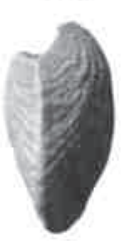

b4

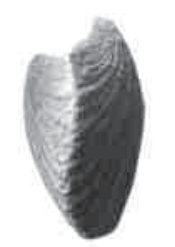

a5
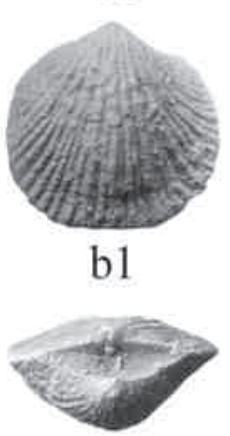

b2

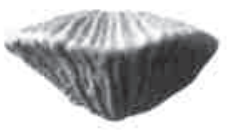

b3

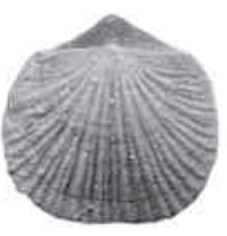

b5

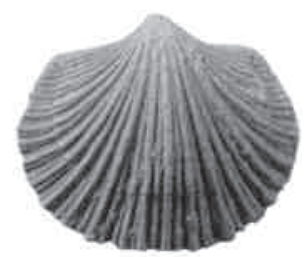

c1

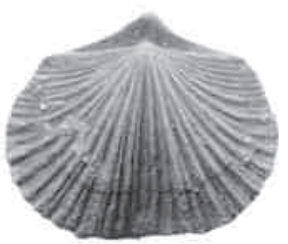

c2

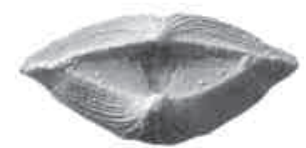

c3

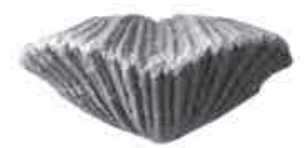

c4
Figure 18. Biernatium sp. 2. Piñeres Fm., lower Frasnian. a1-a5) DPO 48195, ventral, dorsal, posterior, anterior and lateral views. Aramar Beach, locality C-91. 6-9. DPO 48205, ventral, dorsal, posterior, anterior, and lateral views. Aramar, SW El Carmen Point, locality C-195. b1-b5) DPO 48205, ventral, posterior, anterior, lateral, and dorsal views. El Truán Beach, locality C-88. c1-c4) DPO 48200, ventral, dorsal, posterior, and anterior views. Scale bar $=5 \mathrm{~mm}$. 
anterior margins; usually, only first-order secondaries, external in ventral valves and internal in dorsal valves, occur. This ornament pattern is very close to the early growth stages of Biernatium species. On the other hand, $M$. garraensis and $M$. arctica lack a ventral median septum, as does the typical Mystrophora forms, and both are provided with deltidial structures as in Biernatium. All previous data made it plausible Biernatium either evolved from Mystrophora or from the same ancestral trunk in lowermost Pragian or in earlier times. However, more research efforts must be made before arriving to definite conclusions on the relationships among the described forms. Meanwhile any conclusion is likely to be tentative. Unfortunately, very few people have recently paid attention to the subject. In fact, crucial data concerning morphology, ages, and paleogeography coming from the interesting Pragian-Zlichovian northwestern Canada and Australia faunas (Lenz, 1977, 1982; Lenz \& Johnson, 1985) have been ignored in general papers such as the Treatise on Invertebrate Paleontology (Harper, 2000).

The Biernatium sp. 2 ontogeny, as recorded after the different growth stages in the best preserved shells, allows one to draw the assumption that this species evolved from B. sucoi nov. sp. On the other hand, Biernatium sp. 2 is very close to $B$. emanuelensis, and could be near its

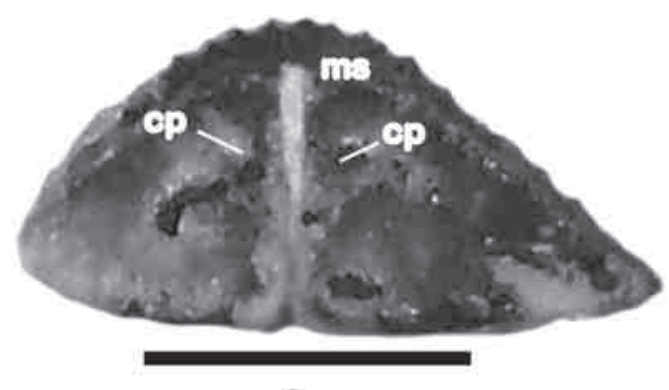

a

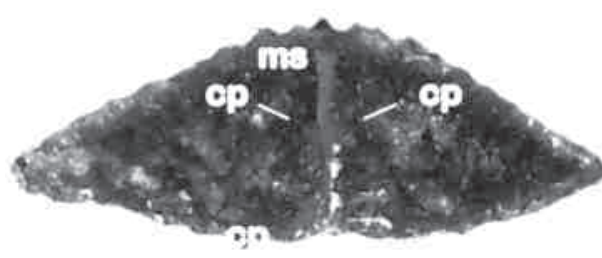

b

Figure 19. Selected serial sections of Biernatium species, showing the disposition and internal structure of the median septum $(m s)$ and crural plates $(c p)$ at midlength of shell. Cruralium very reduced, high on floor of dorsal valve; median septum imbedded in the ventral valve floor. a) Biernatium sucoi nov. sp. DPO 47947. Section to $2.6 \mathrm{~mm}$ from ventral apex (see Fig. 13). b) Biernatium sp. 2, DPO 48198. Section to $2.65 \mathrm{~mm}$ from ventral apex (see Fig. 16). Scale bar $=3 \mathrm{~mm}$. origin. Last by not least, the ornament variation noticed in the discussed species allows one to visualize a longer reaching evolutionary trend relating them back in time to the supposed origin in Mystrophora.

\section{ACKNOWLEDGEMENTS}

This paper is a contribution to projects MINECO CGL2012/34475 "Procesos de formación de mélanges y otras unidades geológicas desorganizadas", and IGCP 596, "Climate change and biodiversity patterns in the MidPalaeozoic (Early Devonian to Late Carboniferous)". The author is particularly indebted to Dr. Robert B. Blodgett, University of Oregon, for his careful English correction and numerous palaeobiogeographical remarks, including the important data concerning the Teichertina occurrence in west-central Alaska. Drs. Enrique Villas Pedruelo and Miguel Vicente Pardo Alonso, from the universities of Zaragoza and Valencia, respectively, are gratefully acknowledged for thorough revision and suggestions that have considerably improved the manuscript.

\section{REFERENCES}

Alekseeva, R.E., Shishkina, G.R., Oleneva, N.V., Afanasjeva, G.A., Komarov, V.N., Grunt, T.A., Roganov, G.V., Eichwald, T.P., Varavatseva, E.E. \& Packnevi, A.V. 2006. Brakhiopody i stratigraphiya Devona Mongolo-Okhotsckoi oblasti (Dalvnii Vostok i Vostochnoe Zabaikalie Rossii, Mongoliya). Trudy Paleontologischeskogo Instituta, Nauka, 285-364 (in Russian).

Anderson, M.M., Boucot, A.J. \& Johnson, J.G. 1969. Eifelian brachiopods from Padaukpin, Northern Shan States, Burma. Bulletin of the British Museum (Natural History), Geology, 18, 107-173.

Bancroft, B.B. 1928. On the notational representation of the rib-system in Orthacea. Manchester Literary and Philosophical Society, Memoirs and Proceedings, 72, 53-90.

Bancroft, B.B. 1945. The brachiopod zonal indices of the stages Costonian to Onnian in Britain. Journal of Paleontology, 19, 181-252.

Barrande, J. 1848. Über die Brachiopoden der silurischen Schichten von Böhmen. Naturwissenschaftliche Abhandlungen, 2, 155-256.

Barrande, J. 1879. Système Silurien du Centre de la Bohême. Iére Partie. Recherches Paléontologiques, vol. 5. Classe des Mollusques. Ordre des Brachiopodes. Published by the author, Prague \& Paris, 226 p.

Biernat, G. 1959. Middle Devonian Orthoidea of the Holy Cross Mountains and their ontogeny. Palaeontologia Polonica, 10, 1-78. 
Bouchard-Chantereaux, M. 1849. Mémoire sur un nouveau genre de brachiopodes formant le passage des formes articulées à celles qui ne le sont pas. Annales des Sciences Naturelles, 3, Zoologie, 12, 84-95.

Cloud, P.E. Jr. 1948. Dicaelosia versus Bilobites. Journal of Paleontology, 22, 373-374.

Cooper, G.A. 1955. New genera of middle Paleozoic brachiopods. Journal of Paleontology, 29, 45-63.

Fernández-Martínez, E., Fernández, L.P., Méndez-Bedia, I. \& Soto, F. 2008. Episodios arrecifales en el Devónico de la región del Cabo de Peñas (Asturias). In: Guía de campo (excursión B) (eds. Ruiz-Omeñaca, J.I., Piñuela, L. \& García-Ramos, J.C.), 24 Jornadas de la Sociedad Española de Paleontología, 1-44.

García-Alcalde, J.L. 1985. La extensión de la biozona de Phlogoiderhynchus (braquiópodo rinconélido, Givetiense terminal-Frasniense inferior). Trabajos de Geología, 15, 77-86.

García-Alcalde, J.L. 1995. L’évolution paléogéographique pré-varisque de la Zone Cantabrique septentrionale (Espagne). Revista Española de Paleontología, 10, 9-29.

García-Alcalde, J.L. 1996. El Devónico del Dominio AsturLeonés en la Zona Cantábrica ( $\mathrm{N}$ de España). Revista Española de Paleontología, $\mathrm{n}^{\mathrm{o}}$ extraordinario, 58-71.

García-Alcalde, J.L., Arbizu, M.A., García-López, S. \& Méndez-Bedia, I. (eds.). 1979. Guidebook Field Trip Meeting International Subcommission Devonian Stratigraphy Spain. Servicio de Publicaciones de la Universidad de Oviedo, 1-41.

García-López, S. 1986. Los conodontos y su aplicación al estudio de las divisiones cronostratigráficas mayores del Devónico asturleonés (España). Boletín Geológico y Minero, 97, 1-112.

García-López, S. \& Sanz-López, J. 2002a. Devonian to Lower Carboniferous conodont biostratigraphy of the Bernesga Valley section (Cantabrian Zone, NW Spain). In: Palaeozoic Conodonts from Northern Spain (eds. García-López, S. \& Bastida, F.). $8^{\text {th }}$ International conodont symposium held in Europe, ECOS VIII, Cuadernos del Museo Geominero, 1, 163-205.

García-López, S. \& Sanz-López, J. (with contributions by Sarmiento, G.N.) 2002b. The Palaeozoic succession and conodont biostratigraphy of the section between Cape Peñas and Cape Torres (Cantabrian coast, NW Spain). In: Palaeozoic Conodonts from Northern Spain (eds. García-López, S. \& Bastida, F.). $8^{\text {th }}$ International conodont symposium held in Europe, ECOS VIII, Cuadernos del Museo Geominero, 1, 125-161.

Godefroid, J. \& Mottequin, B. 2005. Givetian brachiopods from the Trois-Fontaines Formation at Marenne (Belgium, Dinant Synclinorium). Bulletin de l'Institut royal des sciences naturelles de Belgique, 75, 5-23.

Golonka, J. 2002. Plate-tectonic maps of the Phanerozoic. In: Phanerozoic Reef Patterns (eds. Kiessling, W., Flügel, E. \& Golonka, J.). SEPM Special Publication, 72, 21-75.

Gürich, G. 1896. Das Palaeozoicum Polnischen Mittelgebirge. Verhandlungen der Russisch-Kaiserlichen Mineralogischen Gesellschaft zu St. Petersbourg, 32, 1-539.
Halamski, A.T. 2009. Middle Devonian brachiopods from the northern part of the Holy Cross Mountains, Poland in relation to selected coeval faunas. Part One: Introduction, Lingulida, Craniida, Strophomenida, Productida, Protorthida, Orthida. Palaeontographica, 287, 41-98.

Hall, J. \& Clarke, J.M. 1892. An Introduction to the Study of the Genera of the Palaeozoic Brachiopoda. Natural History of New York, Palaeontology, Volume 8, Part 1. New York Geological Survey. Charles van Benthuysen \& Sons, Albany, 367 p.

Harper, D.A.T. 2000. Dalmanellidina. In: Treatise on Invertebrate Paleontology, Part H, Brachiopoda, Revised, Volume 3: Linguliformea, Craniiformea, and Rhynchonelliformea (Part) (ed. Kaesler, L.). The Geological Society of America, Inc, and The University of Kansas, 782-844.

Havlíček, V. 1974. New genera of Orthidina (Brachiopoda) in the Lower Palaeozoic of Bohemia. Vestnik Ústředního ústavu geologického, 49, 167-170.

Havlíček, V. 1975. New species and genera of Orthida (Brachiopoda). Vestník Ústředního ústavu geologického, 50, 231-235.

Havlíček, V. 1977. Brachiopods of the order Orthida in Czechoslovakia. Rozpravy Ustředního ústavu geologického, 44, 1-327.

Johnson, J.G. 1970. Early Middle Devonian brachiopods from central Nevada. Journal of Paleontology, 44, 252-264.

Johnson, J.G. 1972. Teichertina, the last dicaelosiid brachiopod. Journal of Paleontology, 46, 830-835.

Kayser, E. 1871. Die Brachiopoden aus Mittel-und OberDevon der Eifel. Zeitschrift der Deutschen Geologischen Gesellschaft, 23, 491-647.

Kemežys, K.J. 1968. Arrangements of costellae, setae and vascula in enteletacean brachiopods. Journal of Paleontology, 42, 88-93.

Khalfin, L.L. 1937. Srednedevonskie brakhiopody s. Levednskogo, Dichero-Sundenskogo raiona. Izvestia Trudy, 57, 85-148.

Kiessling, W., Flügel, E. \& Golonka, J. 1999. Paleo reef maps: A comprehensive database of Phanerozoic reefs with graphic presentations. American Association of Petroleum Geologists, 83, 1552-1587.

King, W. 1850. A Monograph of the Permian Fossils of England. Palaeontographical Society Monograph, 3, 37, $1-258$.

Kozłowski, R. 1929. Les brachiopodes gothlandiens de la Podolie polonaise. Palaeontologia Polonica, 1, 1-254.

Lenz, A.C. 1977. Upper Silurian and Lower Devonian brachiopods of Royal Creek, Yukon, Canada. Part 1. Orthoidea, Strophomenida, Pentamerida, Rhynchonellida. Palaeontographica, A, 159, 37-109.

Lenz, A.C. 1982. New data on Late Silurian and Early Devonian brachiopods from the Royal Creek area, Yukon Territory. Canadian Journal of Earth Sciences, 19, 364-375; doi: 10.1139/e82-028.

Lenz, A.C. \& Johnson, J.G. 1985. Brachiopods of the Garra Formation (Lower Devonian), Wellington Area, New South Wales, Australia: Orthida, Strophomenida, Pentamerida. Palaeontographica, A, 188, 35-70. 
Lottmann, J. 1990. Die pumilio-Event (Mittel-Devon). Göttinger Arbeiten Geologie und Paläontologie, 44, 1-98.

Maillieux, E. 1936. La faune des schistes de Matagne (Frasnien supérieur). Mémoires du Musée royal d'Histoire Naturelle de Belgique, 1-74.

Méndez-Bedia, I., Soto, F. \& Fernández-Martínez, E. 1994. Devonian reef types in the Cantabrian Mountains (NW Spain) and their faunal composition. Courier Forschungsinstitut Senckenberg, 172, 161-183.

Moore, R.C. 1952. Brachiopoda. In: Invertebrate Fossil (eds. Moore, R.C., Lalicker, C.G. \& Fischer, A.G.). McGrawHill. New York, 197-267.

Perry, D.G. 1984. Brachiopoda and biostratigraphy of the Silurian-Devonian Delorme Formation in the District of Mackenzie, the Yukon. Life Sciences Contributions, Royal Ontario Museum, 138, 1-243; doi: 10.5962/bhl.title.52231.

Quensted, F.A. 1871. Petrefactenkunde Deutschlands: v. 2, Brachiopoden. Tübingen und Leipzig, 748 p.

Renaud, A. 1942. Le Dévonien du Synclinorium Médian Brest-Laval. Mémoires de la Société Géologique et Minéralogique de Bretagne, 7, fascicule 1: Stratigraphie, 1-184; fascicule 2: Paleontologie, 1-439.

Rigaux, E. 1872. Notes pour servir à la géologie du Boulonnais. 1. Déscriptions de quelques brachiopodes du terrain Dévonien de Ferques. Mémoires de la Société Académique de l'Arrondissement de Boulogne-sur-Mer, 5, 47-71.

Rouault, M. 1846. Mémoire sur les trilobites du département d'Ille-et-Vilaine. Bulletin de la Société Géologique de France, 4, 309-328.

Savage, N.M. 1968. Planicardinia, a new septate dalmanellid brachiopod from the Lower Devonian of New South Wales. Palaeontology, 11, 627-632.

Schnur, J. 1851. Die Brachiopoden aus dem Uebergangsgebirge der Eifel. Programm der vereinigten höhern BürgerProvinzial.Gewerbeschule zu Trier, 1-39.
Schnur, J. 1853. Zusammenstellung und Beschreibung sämmtlicher im Uebergangsgebirge der Eifel vorkommenden Brachiopoden. Palaeontographica, 3, 169-248, Cassel.

Schuchert, C. 1913. Class 2. Brachiopoda. In: Text-Book of Palaeontology, Volume 1, Part 1. $2^{\text {nd }}$ edition, MacMillan \& Co., Ltd. London, 355-420 (translated and edited by C. R. Eastman).

Schuchert, C. \& Cooper, G.A. 1931. Synopsis of the Brachiopod Genera of the suborders Orthoidea and Pentameroidea, with notes on the Telotremata. American Journal of Science, serie 5, 22, 241-255; doi: 10.2475/ ajs.s5-22.129.241.

Schuchert, C. \& Cooper, G.A. 1932. Brachiopod genera of the suborders Orthoidea and Pentameroidea. Memoirs of the Peabody Museum of Natural History, xii +270 p.; doi: 10.5962/bhl.title.5732.

Veevers, J.J. 1959. Devonian brachiopods from the Fitzroy basin, Western Australia. Bureau of Mineral Resources, Geology and Geophysics Bulletin, 45, 1-220.

Walmsley, V.G. \& Boucot, A.J. 1975. The phylogeny, taxonomy and biogeography of Silurian and Early to Mid Devonian Isorthinae (Brachiopoda). Palaeontographica, A, 148, 34-108.

Williams, A.J. \& Brunton, C.H.C. 1997. Morphological and anatomical terms applied to brachiopods. In: Treatise on Invertebrate Paleontology (ed. Kaesler, R.L ), Part H, Brachiopoda, Revised, Volume 1, Introduction, 423-440.

Williams, A.J. \& Wright, A.D. 1963. The classification of the "Orthis testudinaria Dalman" group of brachiopods. Journal of Paleontology, 37, 1-32.

Zhang, Y. 1985. Early Middle Devonian (Eifelian) brachiopods from Zhusilenghaierhan region, Western nei Monggol. Acta Palaeontologica Sinica, 24, 243-258 (in Chinese, summarized in English). 
